Prepared in cooperation with the National Park Service

\title{
Annual Ground-Water Discharge by Evapotranspiration from Areas of Spring-Fed Riparian Vegetation Along the Eastern Margin of Death Valley, 2000-02
}

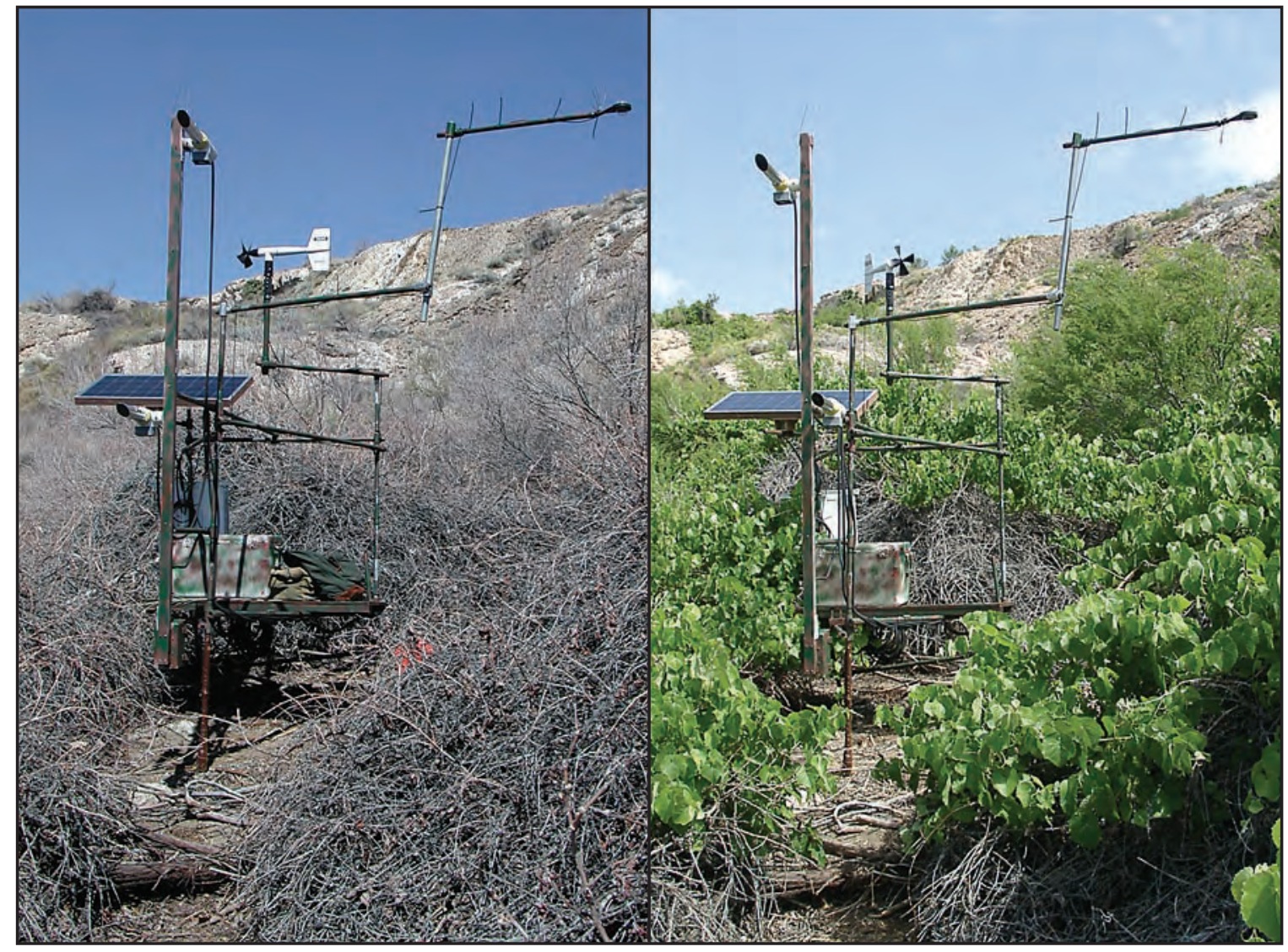

Scientific Investigations Report 2006-5145 
Cover: Evapotranspiration (ET) site in the Grapevine Springs area of Death Valley National Park, Inyo County, California. Site is about 1,000 feet east of Scotty's Ranch house. Foreground vegetation is desert wild grape (Vitis girdiana). Photographs were taken by Randell J. Laczniak, U.S. Geological Survey, March 16, 2001 (left photograph), and May 18, 2001 (right photograph). 


\section{Annual Ground-Water Discharge by Evapotranspiration from Areas of Spring-Fed Riparian Vegetation Along the Eastern Margin of Death Valley, 2000-02}

By Randell J. Laczniak, J. LaRue Smith, and Guy A. DeMeo

Prepared in cooperation with the

National Park Service

Scientific Investigations Report 2006-5145 


\section{U.S. Department of the Interior \\ DIRK A. KEMPTHORNE, Secretary \\ U.S. Geological Survey \\ P. Patrick Leahy, Acting Director}

\section{U.S. Geological Survey, Reston, Virginia: 2006}

For product and ordering information:

World Wide Web: http://www.usgs.gov/pubprod

Telephone: 1-888-ASK-USGS

For more information on the USGS--the Federal source for science about the Earth, its natural and living resources, natural hazards, and the environment:

World Wide Web: http://www.usgs.gov

Telephone: 1-888-ASK-USGS

Any use of trade, product, or firm names is for descriptive purposes only and does not imply endorsement by the U.S. Government.

Although this report is in the public domain, permission must be secured from the individual copyright owners to reproduce any copyrighted materials contained within this report.

Suggested citation:

Laczniak, R.J., Smith J.L., and DeMeo, G.A., 2006, Annual ground-water discharge by evapotranspiration from areas of spring-fed riparian vegetation along the eastern margin of Death Valley, 2000-02: U.S. Geological Survey Scientific Investigations Report 2006-5145, 36 p. Available at URL: http://pubs.water.usgs.gov/sir2006-5145. 


\section{Contents}

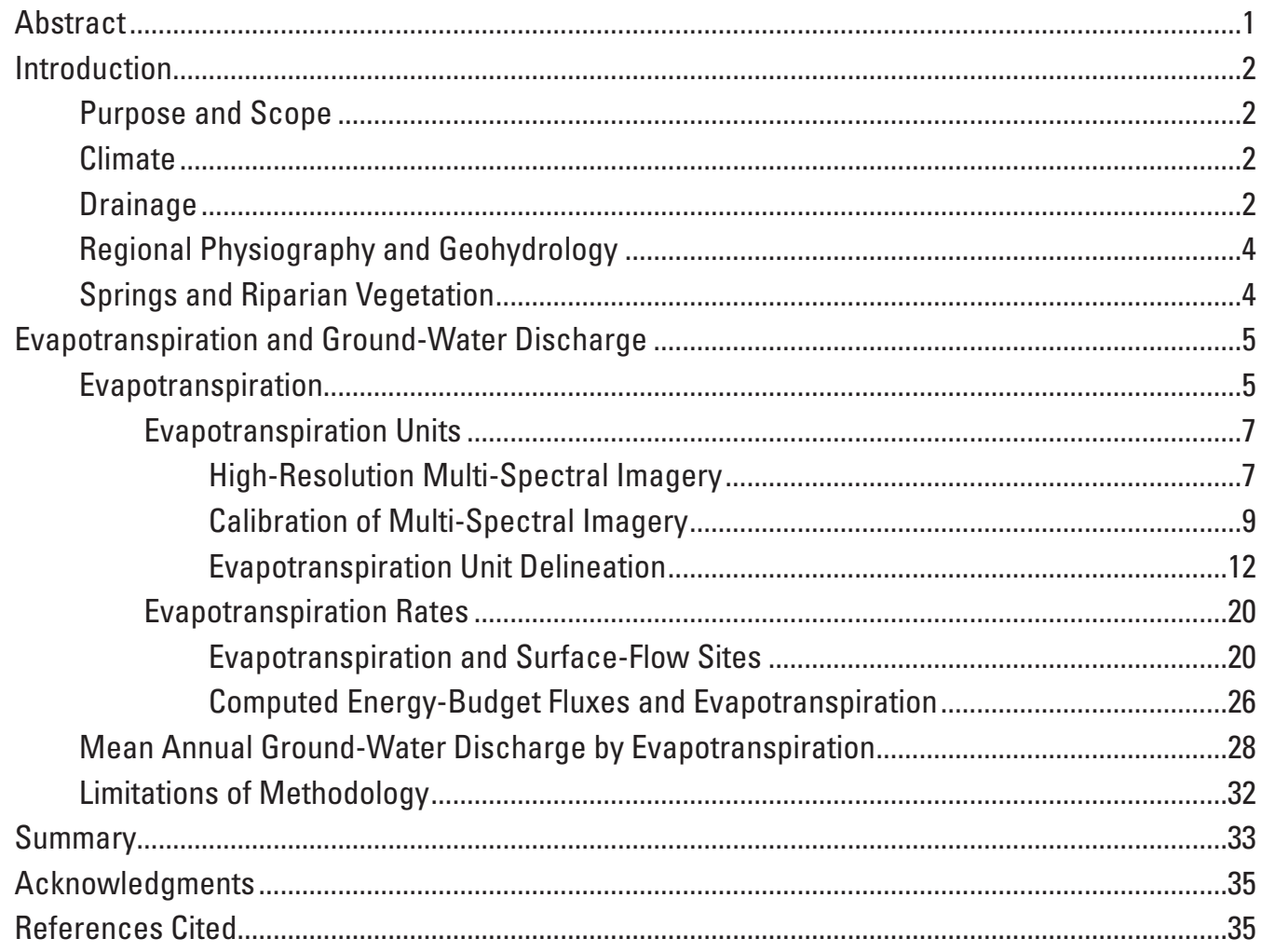




\section{Figures}

Figure 1. Map showing physiography and hydrography of Death Valley area $\ldots \ldots \ldots \ldots \ldots \ldots$

Figure 2. Aerial view of areas of Death Valley imaged by IKONOS satellite in $2001 \ldots \ldots \ldots \ldots .6$

Figure 3. Satellite imagery showing natural-color composites of Furnace Creek Airport showing spatial resolution of IKONOS imagery ............................ 8

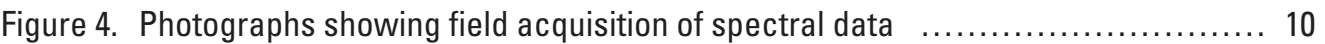

Figure 5. Graph showing field spectra measured over calibration tarps and other vegetated and non-vegetated sites in Furnace Creek and Grapevine Springs areas

Figure 6. Satellite imagery showing spatial distribution of modified soil-adjusted vegetation indices calculated from IKONOS multi-spectral imagery

Figure 7. Map showing distribution of ET units within Grapevine Springs discharge area that were delineated using a modified soil-adjusted vegetation index

Figure 8. Satellite imagery showing distribution of ET units in major spring-discharge areas of the Grapevine Springs imagery that were delineated using a modified soil-adjusted vegetation index

Figure 9. Satellite imagery showing distribution of ET units in major spring-discharge areas of the Furnace Creek imagery that were delineated using a modified soil-adjusted vegetation index

Figure 10. Graphs showing spectral signatures from the IKONOS imagery used to classify ET units within the Grapevine Springs discharge area....

Figure 11. Map showing distribution of ET units that were delineated by land-cover classification in the Grapevine Springs discharge area

Figure 12. Satellite imagery showing data-collection sites in Grapevine Springs discharge area

Figure 13. Schematic and photograph showing instrumentation at Grapevine Springs ET site

Figure 14. Graphs showing micrometeorological data collected at Grapevine Springs ET site, February 20-April 11, 2001

Figure 15. Graphs showing daily minimum, average, and maximum of recorded micrometeorologic measurements collected at Grapevine Springs ET site, September 28, 2000-November 3, 2002

Figure 16. Graphs showing continual ground-water-level, periodic channel-discharge, and precipitation measurements taken at or near Grapevine Springs ET site, September 27, 2000-November 4, 2002

Figure 17. Graph showing computed and measured energy-budget fluxes and measured ground-water level at Grapevine Springs ET site, September 24October 3, 2003

Figure 18. Graph showing daily evapotranspiration and mean daily ground-water level at Grapevine Springs ET site, September 28, 2000-November 3, 2002

Figure 19. Graph showing monthly evapotranspiration (ET) and mean monthly ground-water level at Grapevine Springs ET site, October 2000-0ctober 2002 ..... 30

Figure 20. Graphs showing ground-water level, daily evapotranspiration (ET), daily change in ground-water level, and apparent specific yield at the Grapevine Springs ET site, water year 2002 


\section{Tables}

Table 1. Technical specifications of panchromatic and multi-spectral data acquired by IKONOS satellite

Table 2. Satellite digital numbers and measured percent reflectance for red and near-infrared IKONOS bands over the white and black tarps used in image calibration

Table 3. Description of ET units delineated from multi-spectral IKONOS imagery in major spring-discharge areas along the eastern margin of Death Valley

Table 4. Acreage of ET units within major spring-discharge areas of the Grapevine Springs imagery delineated using a modified soil-adjusted vegetation index

Table 5. Acreage of ET units within major spring-discharge areas of the Furnace Creek imagery that were delineated using a modified soil-adjusted vegetation index

Table 6. Acreage of ET units within major spring-discharge areas of the Grapevine Springs imagery delineated by land-cover classification

Table 7. Acreage of ET units in major spring-discharge areas of the Furnace Creek imagery delineated by land-cover classification

Table 8. Location of data-collection sites in Grapevine Springs area ..................... 20

Table 9. List of equipment used to instrument Grapevine Springs ET site $\ldots \ldots \ldots \ldots \ldots \ldots 22$

Table 10. Periodic water levels measured in shallow well at Grapevine Springs ET site ..... 26

Table 11. Periodic surface-water discharge measured near Grapevine Springs ET site ...... 26

Table 12. Periodic bulk precipitation measured at Grapevine Springs ET site ............... 27

Table 13. Evapotranspiration and ground-water evapotranspiration calculated at Grapevine Springs ET site for three different 365-day periods 30

Table 14. Estimated mean annual ground-water discharge by evapotranspiration from major spring-discharge areas along the eastern margin of Death Valley 


\title{
Conversion Factors and Datums
}

\author{
Conversion Factors
}

\begin{tabular}{|c|c|c|}
\hline Multiply & By & To obtain \\
\hline \multirow[t]{3}{*}{ acre } & 4,047 & square meter $\left(\mathrm{m}^{2}\right)$ \\
\hline & 0.4047 & hectare (ha) \\
\hline & 0.4047 & square hectometer $\left(\mathrm{hm}^{2}\right)$ \\
\hline \multirow[t]{2}{*}{ acre-foot (acre-ft) } & 1,233 & cubic meter $\left(\mathrm{m}^{3}\right)$ \\
\hline & 0.001233 & cubic hectometer $\left(\mathrm{hm}^{3}\right)$ \\
\hline acre-foot per day (acre-ft/d) & 0.01427 & cubic meter per second $\left(\mathrm{m}^{3} / \mathrm{s}\right)$ \\
\hline \multirow[t]{2}{*}{ acre-foot per year (acre-ft/yr) } & 1,233 & cubic meter per year $\left(\mathrm{m}^{3} / \mathrm{yr}\right)$ \\
\hline & 0.001233 & cubic hectometer per year $\left(\mathrm{hm}^{3} / \mathrm{yr}\right)$ \\
\hline foot $(\mathrm{ft})$ & 0.3048 & $\operatorname{meter}(\mathrm{m})$ \\
\hline foot per year (ft/yr) & 0.08345 & centimeter per day $(\mathrm{cm} / \mathrm{d})$ \\
\hline \multirow[t]{2}{*}{ gallon (gal) } & 3.785 & liter $(\mathrm{L})$ \\
\hline & 0.003785 & cubic meter $\left(\mathrm{m}^{3}\right)$ \\
\hline gallon per minute (gal/min) & 0.06309 & liter per second $(\mathrm{L} / \mathrm{s})$ \\
\hline \multirow[t]{3}{*}{ inch (in.) } & 2.54 & centimeter $(\mathrm{cm})$ \\
\hline & 25.4 & millimeter (mm) \\
\hline & 25,400 & micrometer $(\mu \mathrm{m})$ \\
\hline inch per year (in/yr) & 0.06954 & millimeter per day (mm/d) \\
\hline kilowatthour (kWh) & $3,600,000$ & joule $(\mathrm{J})$ \\
\hline mile (mi) & 1.609 & kilometer $(\mathrm{km})$ \\
\hline square mile $\left(\mathrm{mi}^{2}\right)$ & 2.590 & square kilometer $\left(\mathrm{km}^{2}\right)$ \\
\hline pound per square inch $\left(\mathrm{lb} / \mathrm{in}^{2}\right)$ & 6.895 & kilopascal (kPa) \\
\hline pound per square inch $\left(\mathrm{lb} / \mathrm{in}^{2}\right)$ & $68,947.6$ & dyne per square centimeter (dyne/ $\mathrm{cm}^{2}$ ) \\
\hline Watt per square foot $\left(\mathrm{W} / \mathrm{ft}^{2}\right)$ & 10.76 & Watt per square meter $\left(\mathrm{W} / \mathrm{m}^{2}\right)$ \\
\hline
\end{tabular}

Temperature in degrees Fahrenheit $\left({ }^{\circ} \mathrm{F}\right)$ may be converted to degrees Celsius $\left({ }^{\circ} \mathrm{C}\right)$ as:

$$
{ }^{\circ} \mathrm{C}=\left({ }^{\circ} \mathrm{F}-32\right) / 1.8 .
$$

English units are used throughout this report except in cases where units have no English-unit equivalent.

Datums

Vertical coordinate information is referenced to North American Vertical Datum of 1988 (NAVD of 1988).

Horizontal coordinate information is referenced to North American Datum of 1927 (NAD 27).

Altitude refers to a distance above the vertical datum. 


\title{
Annual Ground-Water Discharge by Evapotranspiration from Areas of Spring-Fed Riparian Vegetation Along the Eastern Margin of Death Valley, 2000-02
}

\author{
By Randell J. Laczniak, J. LaRue Smith, and Guy A. DeMeo
}

\section{Abstract}

Flow from major springs and seeps along the eastern margin of Death Valley serves as the primary local water supply and sustains much of the unique habitat in Death Valley National Park. Together, these major spring complexes constitute the terminus of the Death Valley Regional GroundWater Flow System-one of the larger flow systems in the Southwestern United States. The Grapevine Springs complex is the least exploited for water supply and consequently contains the largest area of undisturbed riparian habitat in the park. Because few estimates exist that quantify groundwater discharge from these spring complexes, a study was initiated to better estimate the amount of ground water being discharged annually from these sensitive, spring-fed riparian areas. Results of this study can be used to establish a basis for estimating water rights and as a baseline from which to assess any future changes in ground-water discharge in the park.

Evapotranspiration (ET) is estimated volumetrically as the product of ET-unit (general vegetation type) acreage and a representative ET rate. ET-unit acreage is determined from high-resolution multi-spectral imagery; and a representative ET rate is computed from data collected in the Grapevine Springs area using the Bowen-ratio solution to the energy budget, or from rates given in other ET studies in the Death Valley area. The ground-water component of ET is computed by removing the local precipitation component from the ET rate.

Two different procedures, a modified soil-adjusted vegetation index using the percent reflectance of the red and near-infrared wavelengths and land-cover classification using multi-spectral imagery were used to delineate the ET units within each major spring-discharge area. On the basis of the more accurate procedure that uses the vegetation index, ETunit acreage for the Grapevine Springs discharge area totaled about 192 acres — of which 80 acres were moderate-density vegetation and 112 acres were high-density vegetation.
ET-unit acreage for two other discharge areas delineated in the Grapevine Springs area (Surprise Springs and Staininger Spring) totaled about 6 and 43 acres, respectively; and for the discharge areas delineated in the Furnace Creek area (Nevares Springs, Cow Creek-Salt Springs, Texas Spring, and Travertine Springs) totaled about 29, 13, 11, and 21 acres, respectively. In discharge areas other than Grapevine Springs, watering and spring diversions have altered the natural distribution of the vegetation.

The ET rate for high-density vegetation was estimated from micrometeorological data collected at a site in a dense cluster of desert wild grapes in the Grapevine Springs area. During the peak ET period (June and July), daily ET at the site ranged from about 0.18 to 0.25 inch, and monthly ET ranged from about 5.7 to 6.2 inches. ET totaled about 2.7 feet in water year 2001 (October 2000-September 2001) and totaled about 2.3 feet in water year 2002 (October 2001-September 2002). The mean annual ground water lost by local transpiration and evaporation is estimated to be 2.2 feet. Using this annual rate of 2.2 feet to represent the discharge from high-density vegetation, 2.0 feet per year to represent moderate-density vegetation, and ET-unit acreages delineated from the multispectral imagery, the mean annual discharge of ground water from the Grapevine Springs discharge area by ET is estimated to be 405 acre-feet. Estimates of the annual discharge of ground water by ET from all other major discharge areas ranged from about 9 acre-feet at Surprise Springs to about 61 acre-feet at Nevares Springs. To account for uncertainties in the mean annual ET rate, a reasonable range for the quantity of ground water annually discharged by riparian vegetation at Grapevine Springs is estimated to be from 400 to 550 acre-feet. Because no water is being imported into or diverted out of the Grapevine Springs area, this range also represents an estimate of the quantity of ground water discharged annually from the area's local springs and seeps and of the groundwater requirement of the area's riparian vegetation. 


\section{Introduction}

Ground water flowing from major springs along the eastern margin of Death Valley currently supplies most of the water consumed locally, while also sustaining much of the local habitat supporting the unique flora and fauna of Death Valley National Park (fig. 1). These spring complexes constitute the terminus for the largest part of the Death Valley Regional Ground-Water Flow System (DVRFS; Harrill and others, 1988) that includes much of the western part of southern Nevada. Centrally located within the flow system is the Nevada Test Site, which historically has been used for testing nuclear devices; and Yucca Mountain, which recently has been selected as the single location for storing high-level nuclear waste generated throughout the United States. Past attempts to quantify the amount of ground water discharging from these valley-margin springs have been limited, and typically have focused only on a single spring complex. A more thorough and consistent quantification of the discharge from these local water sources is necessary to establish a sound basis for water rights and a baseline for assessing and documenting future changes in ground-water discharge in the park.

Of the many regional springs that exist along the eastern margin of the Death Valley (fig. 1), the Grapevine Springs complex is the least exploited for water supply and consequently contains the largest area of undisturbed spring-fed riparian habitat within the park boundary. Miller (1977) gives the only available estimate of ground-water discharge from Grapevine Springs in a reconnaissance study. This estimate is based on a limited number of springflow measurements and a cursory estimate of evapotranspiration (ET), and it is considered highly uncertain. A more accurate and reliable estimate of ground-water discharge is necessary for documenting current water needs and developing a better understanding of the long-term sustainability of this sensitive ecosystem. The U.S. Geological Survey (USGS), in cooperation with the National Park Service, began a 3-year study in 2000 to better estimate mean annual ground-water discharge from the Grapevine Springs area and the amount of ground water being transpired by local vegetation at Grapevine Springs and the other major spring complexes along the eastern margin of Death Valley.

\section{Purpose and Scope}

The purpose of this report is to describe the procedures used in the study to develop estimates of (1) ground-water discharge for the Grapevine Springs area and (2) the amount of ground water being evaporated and transpired by local riparian vegetation at the major spring-discharge areas along the eastern margin of Death Valley (fig. 1). These procedures utilize high-resolution, multi-spectral, satellite imagery, and, as a consequence, have generated a variety of digital images for the valley-margin spring-discharge areas that are available from the USGS by accessing the National Spatial Data Infrastructure (NSDI) at URL: 〈http://nsdi.usgs.gov/>. Additionally, this report provides baseline data from which to make comparisons for assessing future changes in groundwater discharge within the park boundary.

The report presents estimates of mean annual groundwater discharge developed from estimates of evaporation and transpiration by the local riparian vegetation. Discharge estimates are not inclusive of any water diverted for human consumption or for operational support by the National Park Service (NPS) and by other private concerns in the park.

\section{Climate}

The climate of the Death Valley area is the most arid in North America. The valley lies primarily in the Mojave Desert, an area characterized by short mild winters, long hot summers, and low annual rainfall and humidity. The wide range in altitude and latitude across the area contributes to climatic conditions that vary dramatically on both seasonal and daily time scales. Temperatures range from winter lows below freezing in the mountains at higher altitudes to summer highs that exceed $120^{\circ} \mathrm{F}$ on the valley floor. The daily temperature range commonly exceeds $30^{\circ} \mathrm{F}$. Precipitation amount, although generally small, varies considerably across Death Valley and depends on altitude, latitude, and location relative to surrounding mountain peaks. Mean annual precipitation ranges from less than 2 in. on the valley floor to more than 10 in. at higher altitudes in the Panamint Range and the Grapevine Mountains (fig. 1; Daly and others, 1994).

\section{Drainage}

Death Valley is the terminal drainage for the DVRFS. Drainage features in Death Valley primarily consist of intermittent streams fed by spring snowmelt or infrequent, major storms. Only a few short reaches, located directly downgradient of major springs, flow year-round. These perennial flows increase in winter, when cooler temperatures and more stressed vegetation result in reduced rates of ET. The two primary drainage features in Death Valley are the Amargosa River in the south and Salt Creek in the north (fig. 1). The Amargosa River, the largest drainage in the region, drains about 5,800 $\mathrm{mi}^{2}$ and is the only major drainage feature that originates outside the valley (fig. 1). 


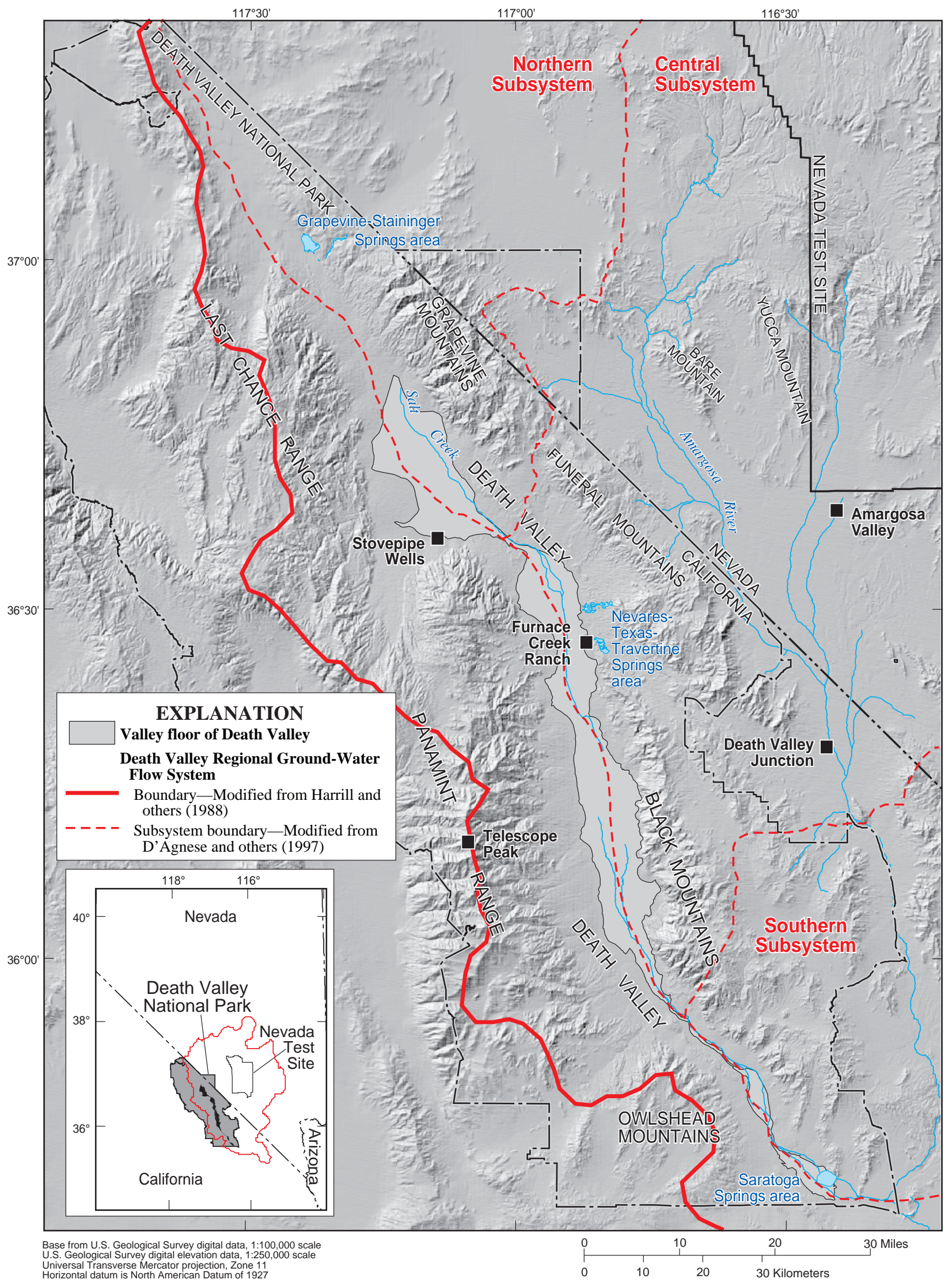

Figure 1. Physiography and hydrography of Death Valley area. 


\section{Regional Physiography and Geohydrology}

Death Valley lies within the southern Great Basin region, an internally drained part of the Basin and Range Physiographic Province. The region is characterized by low rainfall, intermittent streams, large internal surface drainages, and occasional spring-fed oases. The dominant physiographic features are north-trending mountain ranges separating broad, elongated valleys, which formed in response to a long and ongoing period of crustal extension (Stewart, 1980, p. 110); and elevated plateaus, which formed during a period of intense volcanism between about 15 and 8 millions of years ago. Crustal extension has resulted in large vertical displacements along north-trending faults that offset bedrock blocks creating similarly trending mountain ranges separated by alluvial- and fluvial-deposit filled valleys.

Death Valley is situated along the southeastern edge of the Great Basin region. The Panamint Range bounds central Death Valley on the west (fig. 1). This range is one of the highest ranges in the southern Great Basin and rises nearly $12,000 \mathrm{ft}$ above the valley floor to an altitude of about 11,050 ft above NAVD 88 at Telescope Peak (fig. 1). The lowest point in Death Valley, $282 \mathrm{ft}$ below NAVD 88, is in the central part of the valley and is the lowest point on the North American continent.

The major mountain ranges in the southern Great Basin region are composed primarily of pre-Cenozoic rocks of diverse age and lithology (Stewart, 1980). Paleozoic carbonate rock, Paleozoic and Proterozoic siliciclastic rock, and Tertiary volcanic rock constitute the primary rock types of the hills, ridges, and mountain ranges. Intermontane valleys are filled primarily with alluvium and colluvium eroded from surrounding carbonate and volcanic highlands, and lacustrine and palustrine deposits.

The water-transmitting properties of the rocks and the many geologic structures associated with the tectonic history of the area are important controls on the movement of ground water. In general, fractured carbonate rock (limestone and dolomite), fractured volcanic rock (welded tuff and lava flows), and alluvium (sand and gravel) form the major aquifers; whereas the siliciclastic rock (siltstone and quartzite), non-fractured volcanic rock (bedded tuff) and alluvium (silt and clay) form the primary confining units in the region. Faults generally are barriers to ground-water flow but occasionally can act as conduits (Winograd and Thordarson, 1975).

On the basis of rock properties and other geologic and hydrologic information, the Great Basin was divided into 22 regional ground-water flow systems (Harrill and others, 1988). Death Valley is the terminal discharge area for a large (about 16,000 $\mathrm{mi}^{2}$ ) flow system in the southern part of the Great Basin. Ground water in the flow system generally flows through fractured rock and coarser grained sand and gravel deposits southward and westward away from the major recharge areas centered in local and adjacent highlands toward
Death Valley. Much of this water exits the flow system prior to reaching Death Valley at intermediate points of discharge through regional springs and seeps (Winograd and Thordarson, 1975). These springs and seeps typically occur in areas where major fault systems intersect the regional aquifers. Based on flow patterns, D'Agnese and others (1997) identified three primary subsystems within the DVRFS - a northern subsystem that ultimately discharges to springs and seeps at Grapevine Springs and Staininger Spring; a central subsystem that ultimately discharges to Nevares, Texas, and Travertine Springs; and a southern subsystem that ultimately discharges to Saratoga Springs (ig. 1).

\section{Springs and Riparian Vegetation}

Water emerging from mountain, valley-margin, and valley-floor springs supports a large diversity of plants, fish, and local wildlife in the Death Valley area. The highest discharges emerge from springs associated with high-angle faults occurring along the valley margins. These higher discharge areas often include multiple springs and seeps which, as a group, discharge anywhere from a few hundred to a few thousand gallons per minute. Fault-associated springs usually produce warm water with temperatures ranging from about 80 to $100^{\circ} \mathrm{F}$. Valley-floor and mountain springs typically discharge less water at cooler temperatures, usually no more than a few gallons per minute at temperatures less than $80^{\circ} \mathrm{F}$. Saratoga Springs in the southern part of Death Valley is the only large-volume spring on the floor of the valley.

Water discharging from valley-margin springs and seeps infiltrates into the surrounding soils and supports local wetlands around discharge points and riparian vegetation along drainages. Water not evaporated or transpired by the local vegetation flows downward to the water table and laterally toward the valley floor. The riparian vegetation, especially that growing near higher discharge valley-margin springs, provides habitat for numerous species of endemic and rare fish, aquatic insects, and plants, and is dominated by phreatophytes common to desert washes and wetlands, such as desert willow, honey mesquite, desert baccharis, yerba mansa, saltgrass, and desert wild grape. The water emerging from these valley-margin springs is of potable quality and supports less salt-tolerant vegetation than found on the valley floor. Typical vegetation communities associated with these springs are dense to moderately dense, and because of the steeper topography, usually are restricted to areas adjacent to discharge orifices and in narrow drainages. In less steep areas, such as on ledges and pediments, moisture extends outward at shallow depths to support more broad meadows that often are dominated by salt-tolerant species such as saltgrass. Beyond these moist areas, xerophytes dominate the typical landscape. The vegetation in these xerophyte communities is not reliant on spring discharge and includes sparse covers of creosote bush, saltbush, and desert holly. 


\section{Evapotranspiration and Ground-Water Discharge}

Ground water discharges from Death Valley primarily as springflow and seepflow. The largest discharge occurs from regional springs along the eastern margin of Death Valley (fig. 1), including Grapevine Springs and Staininger Spring in the northern part of the valley, Nevares, Travertine, and Texas Springs in the central part of the valley, and Saratoga Springs in the southern part of the valley. Significant quantities of water are diverted from many of the valley-margin springs to meet potable and operational needs associated with ongoing private and Federal activities in the park. The largest diversions occur from Nevares, Texas, and Travertine Springs in central Death Valley and Staininger Spring in northern Death Valley. Diversions are used to support both private and park facilities near Furnace Creek Ranch, park housing and office complexes at Cow Creek Camp near Nevares Spring, and park facilities at Scotty's Castle near Staininger Spring (figs. 1 and 2).

Documented estimates of ground-water discharge from valley-margin springs are limited (Pistrang and Kunkel, 1964; Hunt and others, 1966; and Miller, 1977). Most historical estimates, solely, or in part, are based on limited and periodic springflow records. Estimates of discharge based entirely on springflow and seepflow measurements may be inaccurate if smaller springs and seeps are ignored, if channels are poorly defined, or if in-channel losses are high. However, in areas where most of the springflow and seepflow evaporates or is consumed by the local riparian vegetation, more accurate estimates of ground-water discharge can be derived from estimates of local ET.

\section{Evapotranspiration}

Water loss to the atmosphere by evaporation from open water and soil and transpiration by plants, collectively referred to as evapotranspiration (ET), is a primary mechanism in riparian areas for removing water from the soil and shallow water table. A change in the rate at which water is removed from the ground often is reflected in a change in the depth of the water table or the moisture content of the soil. As more water is removed locally by ET, the water table declines and soils dry. Conversely, as less water is removed, the water table rises and soils moisten. Similar responses in the water table and in the soil moisture content above that water table occur when local springflow changes. Increases in spring and seep discharge can result in more subsurface outflow, more vigorous vegetation, and an expanding riparian habitat; whereas decreases can result in less subsurface outflow, more stressed vegetation, and a dwindling riparian habitat. Changes in ET, the water table, subsurface outflow, and the extent and vigor of riparian vegetation all can be used as indicators of change in local ground-water discharge.
The volume of water lost to the atmosphere through ET can be computed as the product of the ET rate and the acreage of vegetation, open water, moist soil, or some combination thereof that contributes to ET. Past assessments of local and regional ground-water resources have used this calculation to estimate ground-water discharge throughout the DVRFS (Malmberg and Eakin, 1962; Walker and Eakin, 1963; Hunt and others, 1966; Malmberg, 1967; Miller, 1977; Laczniak and others, 1999, 2001; Reiner and others, 2002; and DeMeo and others, 2003).

Hunt and others (1966), Miller (1977), and DeMeo and others (2003) estimated ET from discharge areas in Death Valley. DeMeo and others (2003) focused only on discharge from the valley floor. Hunt and others (1966) focused on the valley south of Stovepipe Wells (fig. 1). Miller (1977) estimated discharge from ET in the Grapevine Springs area (fig. 1) and from springflow measurements elsewhere throughout the valley. The two earlier studies (Hunt and others, 1966; Miller, 1977) estimated ET rates from local pan-evaporation measurements and delineated the acreage contributing to ET using aerial photographs, field reconnaissance, and topographic maps; whereas, DeMeo and others (2003) computed ET rates for different vegetation and soils from energy-balance methods and satellite imagery (LANDSAT Thematic Mapper) to delineate contributing acreage.

This report presents estimates of ET from major springfed riparian areas along the eastern margin of Death Valley using an approach similar to that applied in DeMeo and others (2003) and Laczniak and others (1999, 2001). The underlying assumptions of this approach are that ET rates vary with soil wetness and the vegetation health, density, and type and that these variations can be characterized on the basis of similarities in vegetation and soil conditions. Units delineating areas of similar vegetation and soil conditions are determined on the basis of spectral similarities identified in remotely sensed images in combination with geographic information system techniques. A representative ET rate for each unit is computed from data collected at locations of similar vegetation and soil conditions. The unit ET rate is multiplied by its respective acreage to determine the total ET from the delineated unit. ET from an entire discharge area is calculated by summing the ET estimates for each of its component ET units.

The mean annual amount of ground water discharged by ET is estimated for each of the major springflow and seepflow areas along the eastern margin of Death Valley. These discharge areas include Grapevine Springs, Surprise Springs, and Staininger Spring in the northern part of the valley and Nevares Springs, Salt Springs, Texas Spring, and Travertine Springs in the central part of the valley. Discharge at Saratoga Springs was estimated in a recent study by DeMeo and others (2003). ET estimates given in this study were determined using rates presented in DeMeo and others (2003) and rates computed from micrometeorological data collected in a densely vegetated area near Grapevine Springs. 


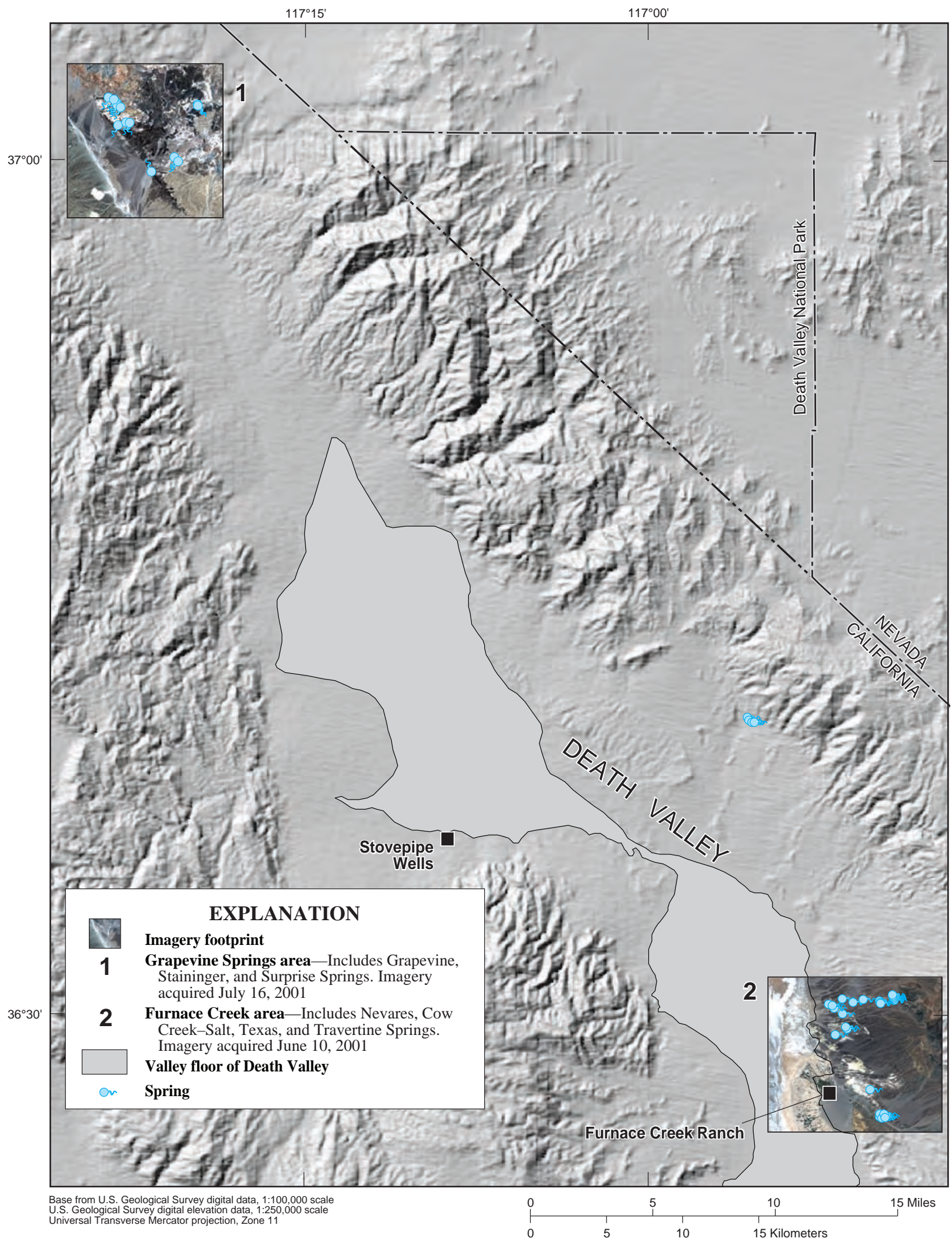

Figure 2. Areas of Death Valley imaged by IKONOS satellite in 2001. 
In addition, high-resolution (13.1 ft) satellite imagery (IKONOS) was acquired and processed as part of this study and was used to accurately delineate the extent and estimate the acreage of riparian vegetation within each major springdischarge area along the eastern margin of Death Valley.

\section{Evapotranspiration Units}

Recent studies have shown that ET from areas of groundwater discharge in the DVRFS varies with vegetation type and density, and soil characteristics (Laczniak and others, 1999, 2001; Reiner and others 2002; DeMeo and others, 2003). In general, the more dense and healthy the vegetation and the wetter the soil, the greater is the ET. These studies used spectral characteristics identified from satellite imagery to delineate similar vegetation and soil groupings within a discharge area. Spectral groupings were based on the degree to which different vegetation and soil reflect incoming solar radiation (Anderson and others, 1976, p. 2; American Society of Photogrammetry, 1983, p. 23-25; Goetz and others, 1983, p. 576-581) and are referred to as ET units in this report.

The mapping of vegetation and soil groupings using remotely sensed, multi-spectral imagery can be done by defining thresholds in a vegetation index or by land-cover classification. A vegetation index typically uses two spectral bands, one representing the red and the other the near-infrared wavelength of the electromagnetic spectrum; a land-cover classification uses all available spectral bands acquired within the visible, near, and short infrared wavelengths of the electromagnetic spectrum (Laczniak, 1999, p. 13-18). Recent studies of ET in the DVRFS (Laczniak and others, 1999, 2001; Reiner and others, 2002; DeMeo and others, 2003) have utilized Thematic Mapper (TM) imagery to map ET units. TM imagery has a resolution of about $100 \mathrm{ft}$ (pixel size of about $100 \mathrm{ft}$ by $100 \mathrm{ft}$ ) and includes six bands spanning wavelengths between 0.45 and 2.35 microns. TM imagery, although appropriate for delineating areas of broad, extensive vegetation, is less useful in smaller, more constrained areas of vegetation. Most vegetation common throughout the many spring-fed riparian areas along the eastern margin of Death Valley is restricted to relatively narrow drainages typically less than $50 \mathrm{ft}$ in width. The spatial constraints imposed by the local vegetation preclude TM imagery as an accurate method to map ET units.

\section{High-Resolution Multi-Spectral Imagery}

High-resolution multi-spectral imagery was used to group riparian vegetation within the major spring-discharge areas along the eastern margin of Death Valley into general ET units delineated primarily on the basis of vegetation density. This high-resolution imagery was acquired by the IKONOS satellite that is equipped with sensors to measure reflected solar radiation from the Earth's surface and radiation scattered from the atmosphere. Multi-spectral measurements of reflected and scattered radiation are made by the satellite imaging four bands, each spanning discrete wavelength bands within the visible or near-infrared (NIR) region of the electromagnetic spectrum. A more spatially resolved fifth band, referred to as the panchromatic band, also is acquired. This band spans a broader portion of the electromagnetic spectrum from the visible through near-infrared region. Band characteristics and spatial resolution of IKONOS panchromatic and multi-spectral data are listed in table 1.

Two areas in Death Valley were imaged as part of this study-Furnace Creek and Grapevine Springs (fig. 2). The Furnace Creek imagery was acquired on June 10, 2001, and Grapevine Springs imagery on July 16, 2001. Both panchromatic and multi-spectral data were acquired. In addition, pan-sharpened, natural-color images also were purchased. The pan-sharpening process produces higher resolution color images than could be achieved from the multi-spectral data alone. Although the sharpening process alters individual multi-spectral radiance values such that the image becomes unsuitable for most image processing procedures used to delineate and identify vegetation, the near aerial-photograph quality images were used to refine vegetation boundaries delineated from the multi-spectral data. Multi-spectral and pan-sharpened images of the Furnace Creek area generated from IKONOS data are compared in figure 3. IKONOS data were orthorectified for improved spatial accuracy. The rectification process removes distortions introduced during acquisition and resamples the image to a uniform grid size based on the specified map projection. The imagery acquired for this study has a root mean square error accuracy of $\pm 13.1 \mathrm{ft}$. Spatial attributes are stored as Universal Transverse Mercator (UTM) coordinates referenced to North American Datum of 1983 (NAD83).

Table 1. Technical specifications of panchromatic and multispectral data acquired by IKONOS satellite.

[PAN, panchromatic; MS, multi-spectral; NIR, near-infrared]

\begin{tabular}{lllc}
\hline Sensor & Band & $\begin{array}{c}\text { Spectral range, } \\
\text { in micrometers }\end{array}$ & $\begin{array}{c}\text { Spatial } \\
\text { resolution, } \\
\text { in feet }\end{array}$ \\
\hline PAN & 1 & $0.526-0.928$ & 3.28 \\
MS & 1 (blue) & $0.445-0.516$ & 13.1 \\
MS & 2(green) & $0.506-0.595$ & 13.1 \\
MS & 3 (red) & $0.632-0.698$ & 13.1 \\
MS & 4 (NIR) & $0.757-0.853$ & 13.1 \\
\hline
\end{tabular}



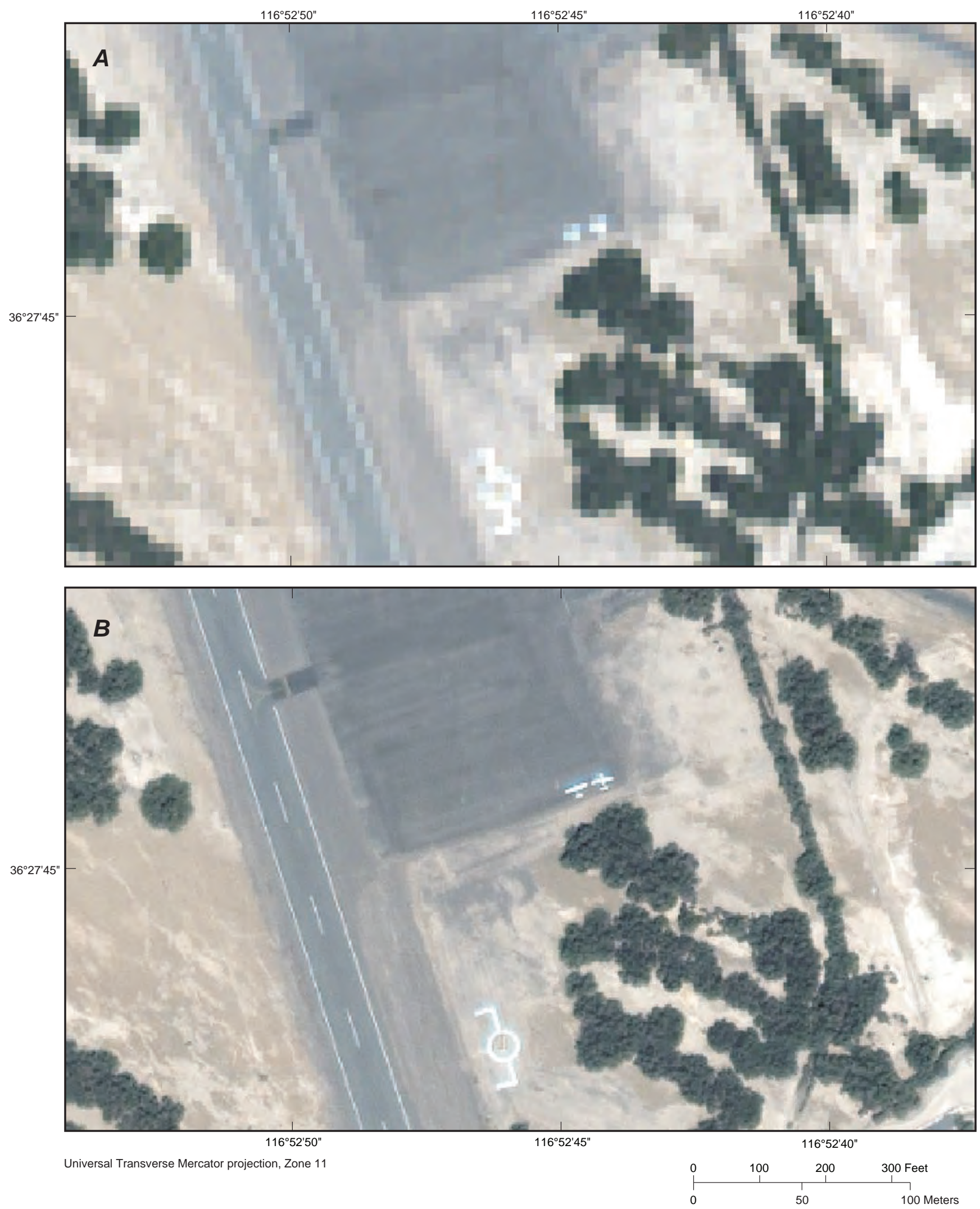

Figure 3. Natural-color composites of Furnace Creek Airport showing spatial resolution of IKONOS imagery. $(A)$ Thematic imagery and $(B)$ IKONOS imagery. 


\section{Calibration of Multi-Spectral Imagery}

Spectral variations in individual pixel values of a multispectral image are caused primarily by differences in the way a land cover reflects solar energy. However, astronomic factors and atmospheric conditions can dramatically affect the spectral response measured by the satellite sensor by introducing temporal inconsistencies. These temporal inconsistencies make the development of a relation between spectral response and a specific land cover exceedingly difficult. One procedure commonly used to remove or reduce astronomic and atmospheric effects is to calibrate the imagery to reflectance values measured over a light and dark ground surface. The calibration process converts digital numbers acquired by the satellite to an apparent percent reflectance value for a given land cover.

The IKONOS imagery was calibrated using two large tarps (20 ft by $20 \mathrm{ft}$ ) placed on the ground during image acquisition. A black tarp was used to represent a dark body, and a white tarp to represent a bright body. The tarps were laid on a flat surface behind the National Park Service facility at Park Village near Furnace Creek. A solar radiometer was placed near the tarps to measure incoming solar radiation. Tarps were set out for about a 2-hour period on each day the satellite passed, straddling the time at which the satellite was to acquire the imagery.

The reflectance of each tarp was measured with an Analytical Spectral Devices (ASD) spectrometer. The instrument is a high performance single-beam field spectrometer that measures reflectance over the visible to short-wave infrared (SWIR) wavelength range and acquires single spectra in milliseconds from 0.35 to 2.50 microns. Reflectance data were collected on June 19, 2001, when outside temperatures ranged from just over $90^{\circ} \mathrm{F}$ in the late morning to over $105^{\circ} \mathrm{F}$ by late afternoon.

Spectra data also were collected at nine other sites between 9 a.m. and 3 p.m. These sites characterize homogeneous inorganic surfaces and specific vegetation species. Inorganic areas include the tarmac at the Furnace Creek airport, light tan clay deposits, the sand and gravel material near the tarp location, tan soil flooring of an old corral, and a gray sand and pebble xerophytic cover. Vegetation species include mesquite, saltcedar, desert wild grape, arrowweed, and seepweed. Typical spectra acquisitions are shown in figure 4. Field spectra acquired over tarps and vegetated and non-vegetated sites are plotted in figure 5. The reflectance of the black tarp tends to be consistent across the spectrum while that of the white tarp decreases dramatically at the higher wavelengths in the infrared region. The decrease in white reflectance is not problematic to the calibration of IKONOS data because IKONOS imagery includes only shorter wavelength bands.
Digital numbers in the two multi-spectral IKONOS images, representing the raw scaled-radiance values measured by the satellite sensor, were converted to percent reflectance using field spectra from the black and white tarps as calibration end points. Calibration tarps were recognized easily in the pan-sharpened and multi-spectral images of the Furnace Creek area. Digital numbers for pixels associated with the black tarp were lower than those associated with other pixels in the image, and numbers associated with the white tarp were higher. Field spectra for each tarp were converted to percent reflectance and averaged across the wavelengths defined by each IKONOS band. Averaged values were used as end points to develop linear equations that were used to convert digital numbers to percent reflectance. The measured percent reflectance and imaged digital numbers for the red and near-infrared bands of the black and white tarps are listed in table 2.

Although the two IKONOS images were acquired on different days and are separated by a distance of about $50 \mathrm{mi}$, the corrections used to calibrate the Furnace Creek imagery also were used to calibrate the Grapevine Springs imagery. In addition to distance, differences in atmospheric conditions caused by changes in windblown particulates also could affect the accuracy of the calibration. To evaluate potential differences in atmospheric conditions, solar-radiation data collected at the tarp site during both imagery acquisition periods were compared. Similarities in incoming solar radiation indicate similar atmospheric conditions during both acquisition periods, thus supporting the calibration of the Grapevine Springs imagery using the corrections developed for the Furnace Creek imagery.

Following calibration, field spectra were compared to IKONOS-derived reflectance values. Differences between reflectance values ranged from about 0.83 to 3.23 percent in the Furnace Creek area and from about 0.6 to 1.9 percent in the Grapevine Springs area. The small differences between field measurements and the calibrated imagery support the accuracy of the calibration procedure.

Table 2. Satellite digital numbers and measured percent reflectance for red and near-infrared IKONOS bands over the white and black tarps used in image calibration.

[DN, digital number; NIR, near-infrared]

\begin{tabular}{lcccc}
\hline $\begin{array}{l}\text { IKONOS } \\
\text { channel }\end{array}$ & $\begin{array}{c}\text { White } \\
\text { DN }\end{array}$ & $\begin{array}{c}\text { Black } \\
\text { DN }\end{array}$ & $\begin{array}{c}\text { White } \\
\text { reflectance }\end{array}$ & $\begin{array}{c}\text { Black } \\
\text { reflectance }\end{array}$ \\
\hline 3 (red) & 2029 & 385 & 0.909 & 0.0588 \\
4 (NIR) & 1893 & 261 & 0.901 & 0.0594 \\
\hline
\end{tabular}




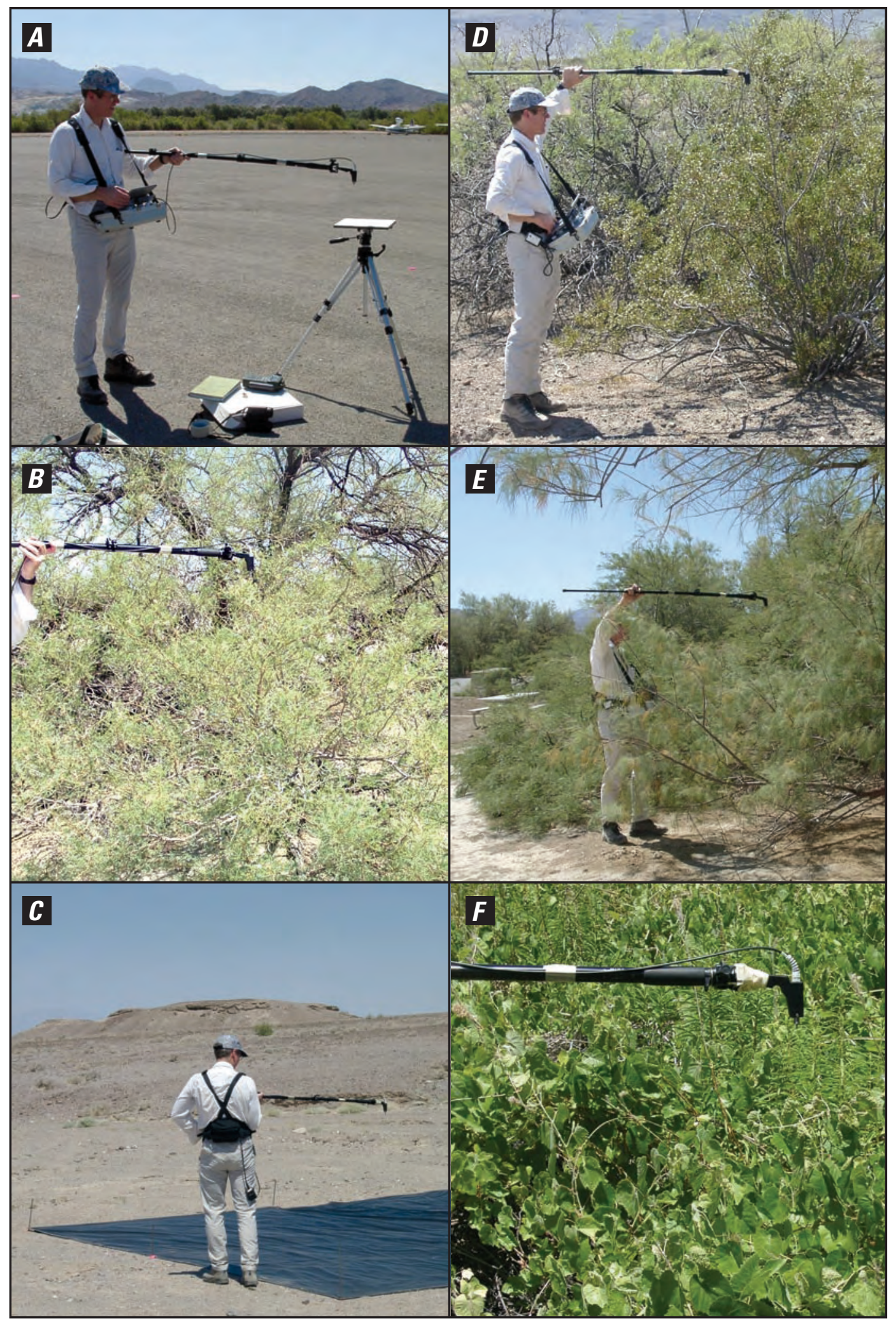

Figure 4. Field acquisition of spectral data. $(A)$ Airport tarmac; $(B)$ Mesquite; $(C)$ Black tarp; $(D)$ Creosote bush; (E) Saltcedar; and $(F)$ Desert wild grape. 


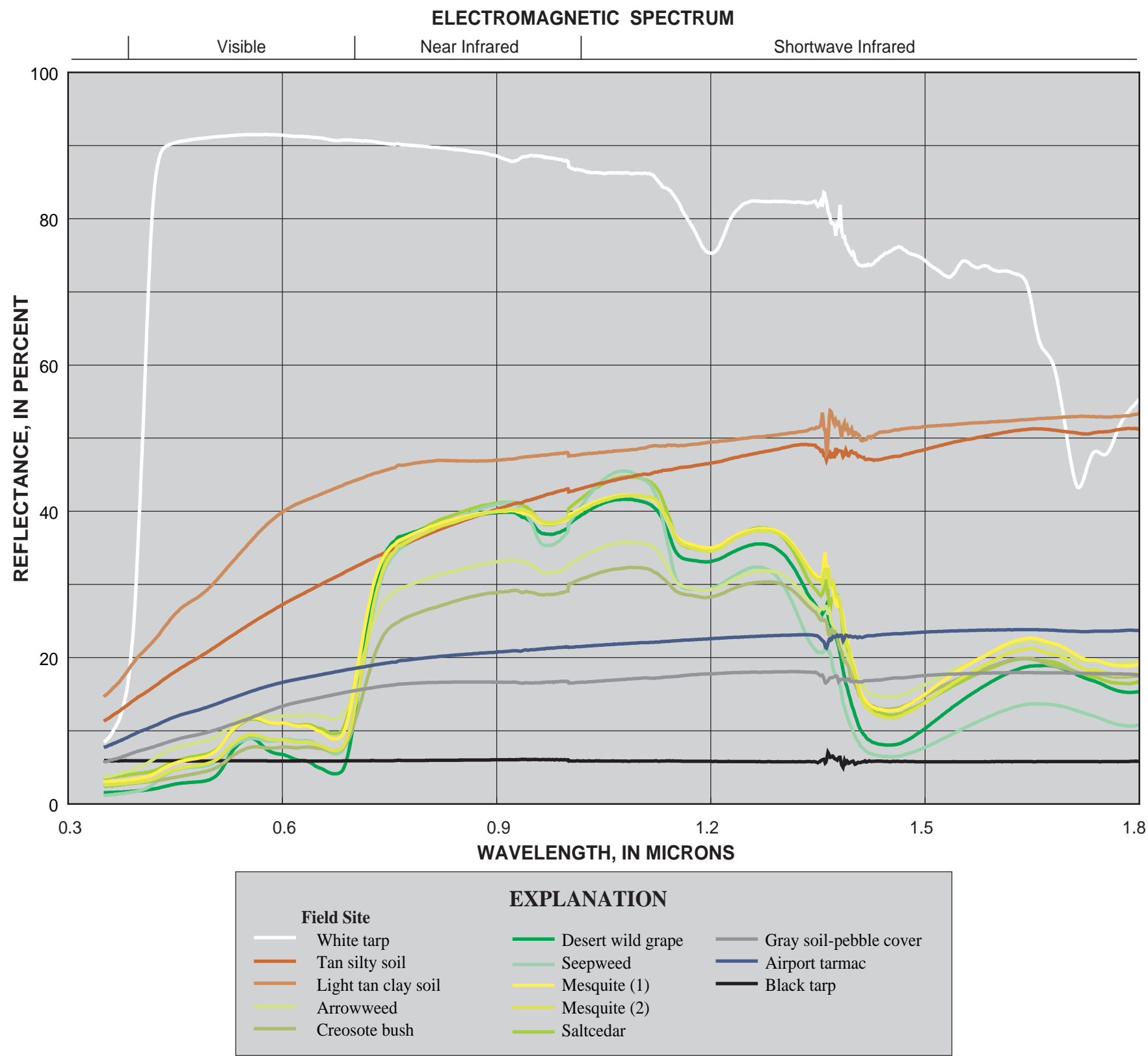

Figure 5. Field spectra measured over calibration tarps and other vegetated and non-vegetated sites in Furnace Creek and Grapevine Springs areas. 


\section{Evapotranspiration Unit Delineation}

Two ET units (table 3 ) were delineated within each of the major spring-discharge areas along the eastern margin of Death Valley. Units were delineated independently from the calibrated IKONOS imagery using two different proceduresa vegetation index and a land-classification analysis. Because the study focus is on Grapevine Springs, the criteria used to delineate ET units was developed in the Grapevine Springs area and applied to other major discharge areas of interest. Unit delineations are not intended to be exact but rather generalizations of spatial changes in the vegetation density in an area.

The modified soil-adjusted vegetation index (MSAVI) developed by Qi and others (1994) was used to delineate ET units in the study area. The MSAVI was selected because it is one of only a few indices that attempts to reduce influences of bare soil. As is typical of most vegetation indices, the MSAVI is calculated using the percent reflectance of the red (band 3) and near-infrared (band 4) wavelengths. The index performs favorably for vegetation conditions typical of desert environments, and has been applied successfully by Nichols (2000) and Berger and others (2001) in ET studies of central Nevada. MSAVI distributions computed for the Grapevine Springs and Furnace Creek areas are shown in figure 6.

Dimensionless MSAVI values range from -1 to 1 , with higher values indicating denser vegetation. An MSAVI value of 0.14 was determined to be the lower threshold of moderately dense vegetation, and a value of 0.25 to be the lower threshold of high-density vegetation. These threshold values were determined by comparing areas of known vegetation with MSAVI pixel values. Areas of moderate- and high-density vegetation were delineated by assigning pixels based on these "break" values to density groups listed in table 3 . This process involved numerous iterations whereby vegetation groupings delineated from the imagery were field checked and noted differences remedied by adjusting the MSAVI threshold values until field and computed delineations were in general agreement. ET-unit acreage determined by this process for the Grapevine Springs area totals about 192 acres - of which 79 acres are moderate-density vegetation and 112 acres are high-density vegetation. MSAVI-delineated ET units in the Grapevine Springs discharge area are shown in figure 7.

Threshold values used to delineate ET units in the Grapevine Springs discharge area also were used to delineate ET units at Surprise Springs and Staininger Spring (fig. 8). ET-unit acreage for Grapevine Springs, Surprise Springs, and Staininger Spring discharge areas total about 240 acres (table 4).

ET units within the major spring-discharge areas of the Furnace Creek imagery were delineated using the same threshold MSAVI values established for the Grapevine Springs area (fig. 9). ET-unit acreage in the major spring-discharge areas of the Furnace Creek imagery total about 74 acres (table 5). Visual observations indicate that the distribution of vegetation in these discharge areas has been affected by spring diversion for local water supply and lawn irrigation.

Table 3. Description of ET units delineated from multi-spectral IKONOS imagery in major spring-discharge areas along the eastern margin of Death Valley.

\begin{tabular}{lcc}
$\begin{array}{c}\text { ET-unit } \\
\text { identifier }\end{array}$ & $\begin{array}{c}\text { ET-unit } \\
\text { number }\end{array}$ & General description of ET unit ${ }^{2}$ \\
\hline MDV & $1 \quad \begin{array}{c}\text { Area of moderate-density vegetation, primarily saltgrass, bunch grass, yerba mansa, arrowweed, desert } \\
\text { baccharis, mesquite or some combination thereof; water table typically less than } 5 \text { feet below land surface in } \\
\text { winter and ranges from near land surface to about } 15 \text { feet below land surface in summer; soil moist in winter } \\
\text { and damp to dry in summer. }\end{array}$ \\
HDV & $\begin{array}{c}\text { Area dominated by high-density vegetation, primarily desert wild grape, mesquite, desert willow, arrowweed, } \\
\text { or some combination thereof; some areas have minor presence of saltgrass, bunch grass, and date palms; } \\
\text { water table typically ranges from near surface to } 10 \text { feet below land surface; soil wet to moist in winter and } \\
\text { moist to dry in summer. }\end{array}$ \\
&
\end{tabular}

\footnotetext{
${ }^{1}$ Areas within the imagery of no substantial ET from a ground-water source were assigned a unit number of zero. These areas are characterized by a water table greater than 15 feet below land surface and very dry soil. Vegetation present in these areas typically is not phreatophytic and is of much lower density than classified areas.

${ }^{2}$ Vegetation cover descriptor: Moderate is about 20 to 50 percent phreatophyte cover and dense is greater than 50 percent. Soil moisture descriptor presented in qualitative terms. Depth-to-water information based on observation, data stored in U.S. Geological Survey National Water Information System (retrieved June 2003), and periodic and continual depth-to-water measurements made during the study.
} 


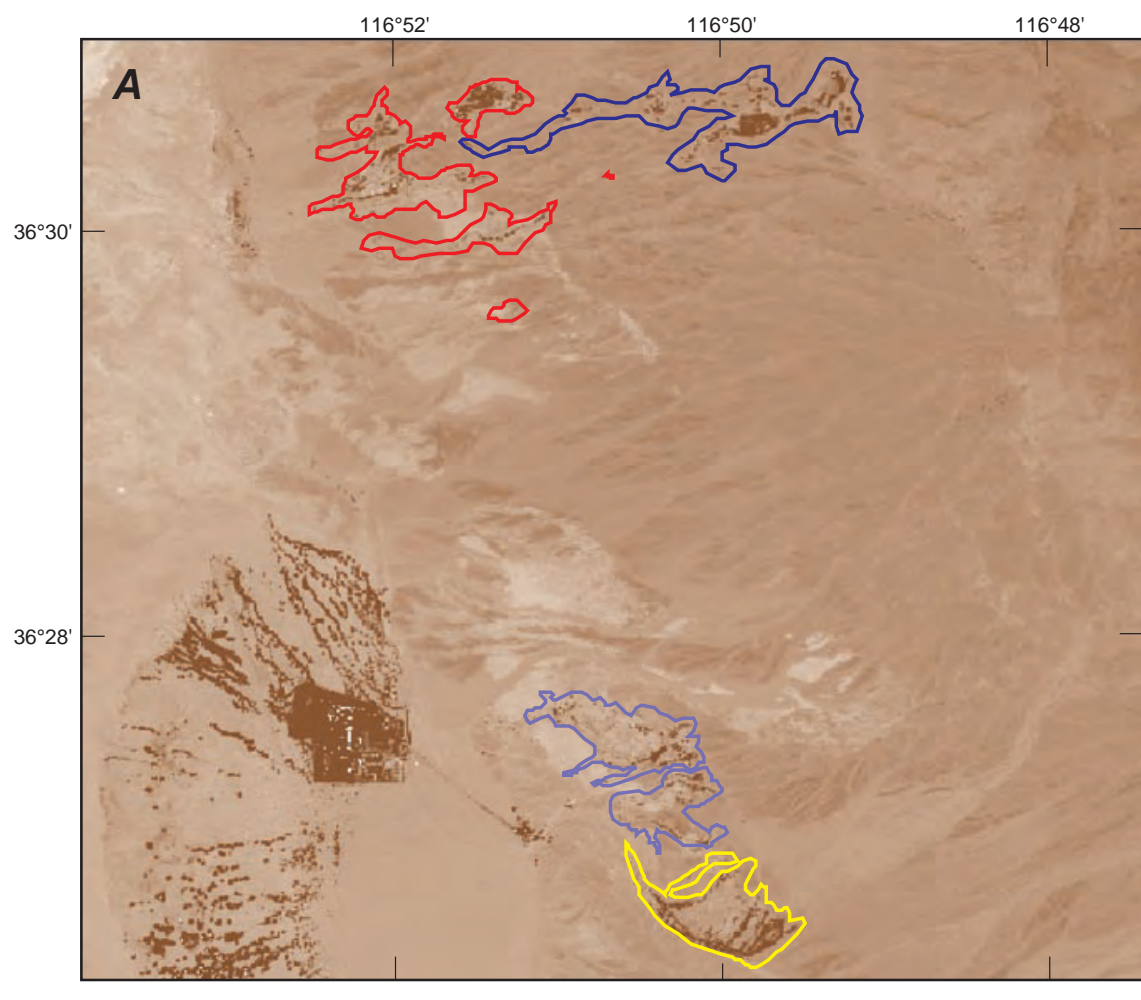

\begin{tabular}{|c|}
\hline EXPLANATION \\
Valley-margin spring-discharge area \\
Furnace Creek area \\
Nevares Springs \\
Cow Creek-Salt Springs \\
Texas Spring \\
Travertine Springs \\
Grapevine Springs area \\
$\quad$ Grapevine Springs \\
$\quad$ Surprise Springs \\
\hline$\quad$ Staininger Spring
\end{tabular}
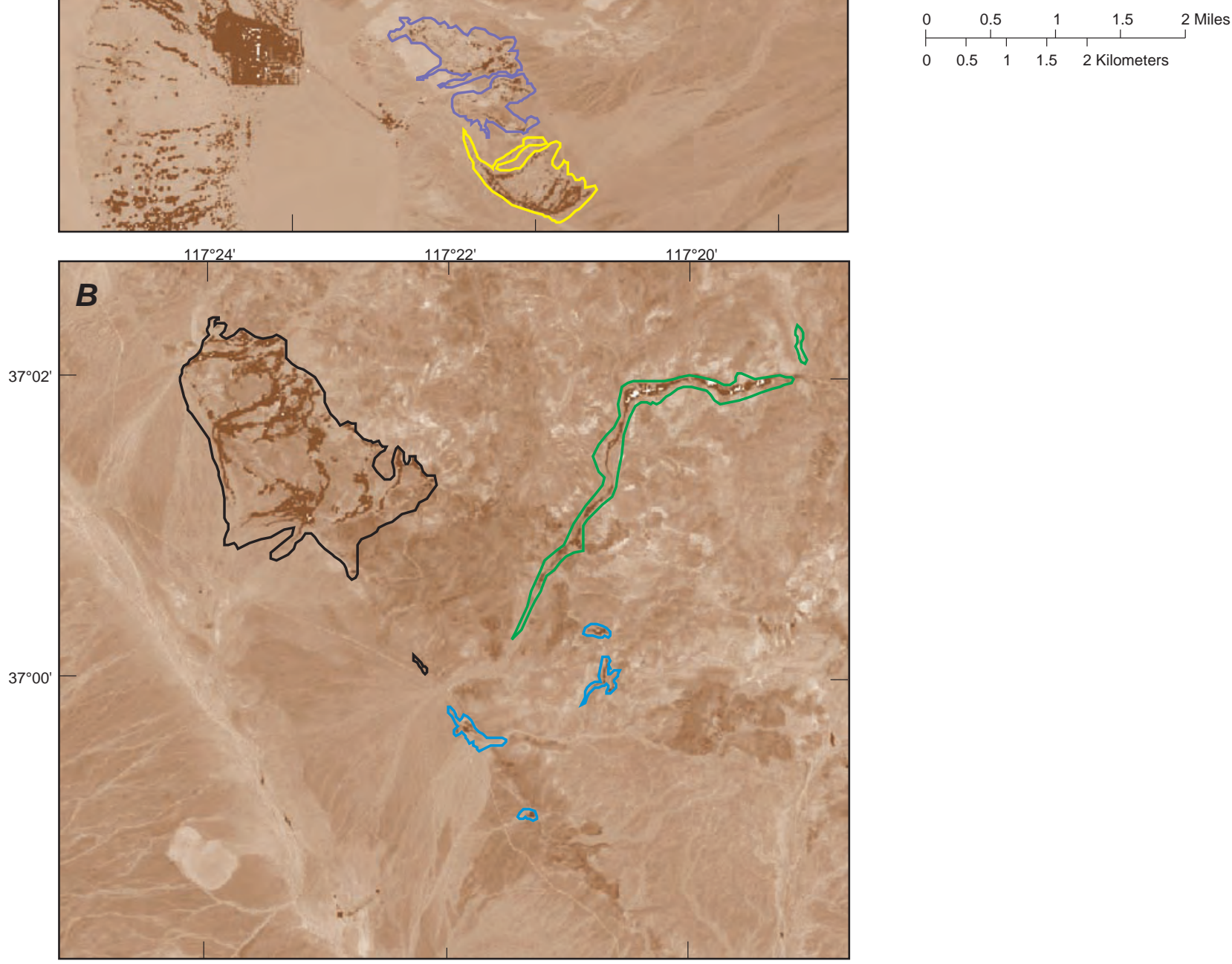

Universal Transverse Mercator projection, Zone 11

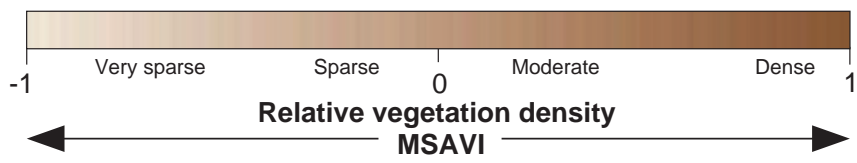

Figure 6. Spatial distribution of modified soil-adjusted vegetation indices calculated from IKONOS multi-spectral imagery. $(A)$ Furnace Creek and $(B)$ Grapevine Springs areas. 
Table 4. Acreage of ET units within major spring-discharge areas of the Grapevine Springs imagery delineated using a modified soil-adjusted vegetation index.

[Spring-discharge areas shown in figure 8]

\begin{tabular}{|c|c|c|c|}
\hline \multirow{2}{*}{$\begin{array}{l}\text { Spring- } \\
\text { discharge } \\
\text { area }\end{array}$} & \multicolumn{3}{|c|}{ ET-unit acreage, in acres } \\
\hline & $\begin{array}{c}\text { Moderate } \\
\text { density }\end{array}$ & $\begin{array}{c}\text { High } \\
\text { density }\end{array}$ & Total \\
\hline Grapevine Springs & 79.4 & 112.0 & 191.4 \\
\hline Staininger Spring & 20.9 & 22.5 & 43.4 \\
\hline Surprise Springs & 4.1 & 2.2 & 6.3 \\
\hline Total & 104.4 & 136.7 & 241.1 \\
\hline
\end{tabular}

Table 5. Acreage of ET units within major spring-discharge areas of the Furnace Creek imagery that were delineated using a modified soil-adjusted vegetation index.

[Spring-discharge areas shown in figure 9]

\begin{tabular}{|c|c|c|c|}
\hline \multirow{2}{*}{$\begin{array}{c}\text { Spring- } \\
\text { discharge area }\end{array}$} & \multicolumn{3}{|c|}{ ET-unit acreage, in acres } \\
\hline & $\begin{array}{l}\text { Moderate } \\
\text { density }\end{array}$ & $\begin{array}{c}\text { High } \\
\text { density }\end{array}$ & Total \\
\hline Nevares Springs & 13.6 & 15.4 & 29 \\
\hline Cow Creek-Salt Springs & 5 & 7.6 & 12.6 \\
\hline Texas Spring & 5.4 & 5.8 & 11.2 \\
\hline Travertine Springs & 9.8 & 11.6 & 21.4 \\
\hline Total & 33.8 & 40.4 & 74.2 \\
\hline
\end{tabular}

ET units also were delineated independently using a land-cover classification. This process groups pixels into ET units on the basis of similarities in the shape and magnitude of their spectral response. A pixel's spectral response, or spectral signature, typically is defined by the percent reflectance of all available bands in the visible and near-infrared regions of the electromagnetic spectrum (spectral bands 1, 2, 3, and 4 in IKONOS imagery). This procedure has been used successfully to delineate ET units in the major discharge areas of the DVRFS (Laczniak and others, 1999, 2001; Reiner and others, 2002). These studies provide additional detail on the landclassification process.
Unique sets of spectral signatures based on the four IKONOS bands were generated for the Grapevine Springs area using an unsupervised classification. The procedure identified a finite number of spectral signatures in the Grapevine imagery using the clustering method presented by Tou and Gonzalez (1974). These same signatures also were used to classify ET units in discharge areas in the Furnace Creek imagery. The classification process then assigned a spectral signature to each pixel in an image that was most similar in character. This process resulted in eight unique vegetation signatures for the Grapevine Springs area-three of which were combined to represent moderate-density vegetation and five of which were combined to represent high-density vegetation (fig. 10). Within the Grapevine Springs discharge area, ET-unit acreage delineated by land classification totals about 189 acres - 88 acres of which are moderate-density vegetation and 101 acres are high-density vegetation (table 6).

ET units in Staininger Spring and Surprise Springs discharge areas were delineated by land classification using the eight spectral signatures used to classify pixels in the Grapevine Springs discharge area (fig. 11). ET-unit acreage delineated by land-cover classification for the Grapevine Springs, Staininger Spring, and Surprise Springs discharge areas totals 239 acres (table 6) and is nearly equivalent to that delineated from MSAVI values (table 4). The maximum difference in ET-unit acreage calculated by land-cover classification and MSAVI procedures for a discharge area in the Grapevine Springs imagery is about 1 percent, and for the acreage of any individual ET unit is about 11 percent (tables 4 and $\underline{6}$ ). The difference in acreage calculated for any one ET unit in a discharge area in the Grapevine Springs imagery is offset by that calculated for another ET unit.

Table 6. Acreage of ET units within major spring-discharge areas of the Grapevine Springs imagery delineated by land-cover classification.

[Spring-discharge areas shown in figure 8]

\begin{tabular}{|c|c|c|c|}
\hline \multirow{2}{*}{$\begin{array}{l}\text { Spring- } \\
\text { discharge } \\
\text { area }\end{array}$} & \multicolumn{3}{|c|}{ ET-unit acreage, in acres } \\
\hline & $\begin{array}{c}\text { Moderate } \\
\text { density }\end{array}$ & $\begin{array}{c}\text { High } \\
\text { density }\end{array}$ & Total \\
\hline Grapevine Springs & 88.1 & 101.0 & 189.1 \\
\hline Staininger Spring & 20.0 & 23.7 & 43.7 \\
\hline Surprise Springs & 3.8 & 2.4 & 6.2 \\
\hline Total & 111.9 & 127.1 & 239.0 \\
\hline
\end{tabular}




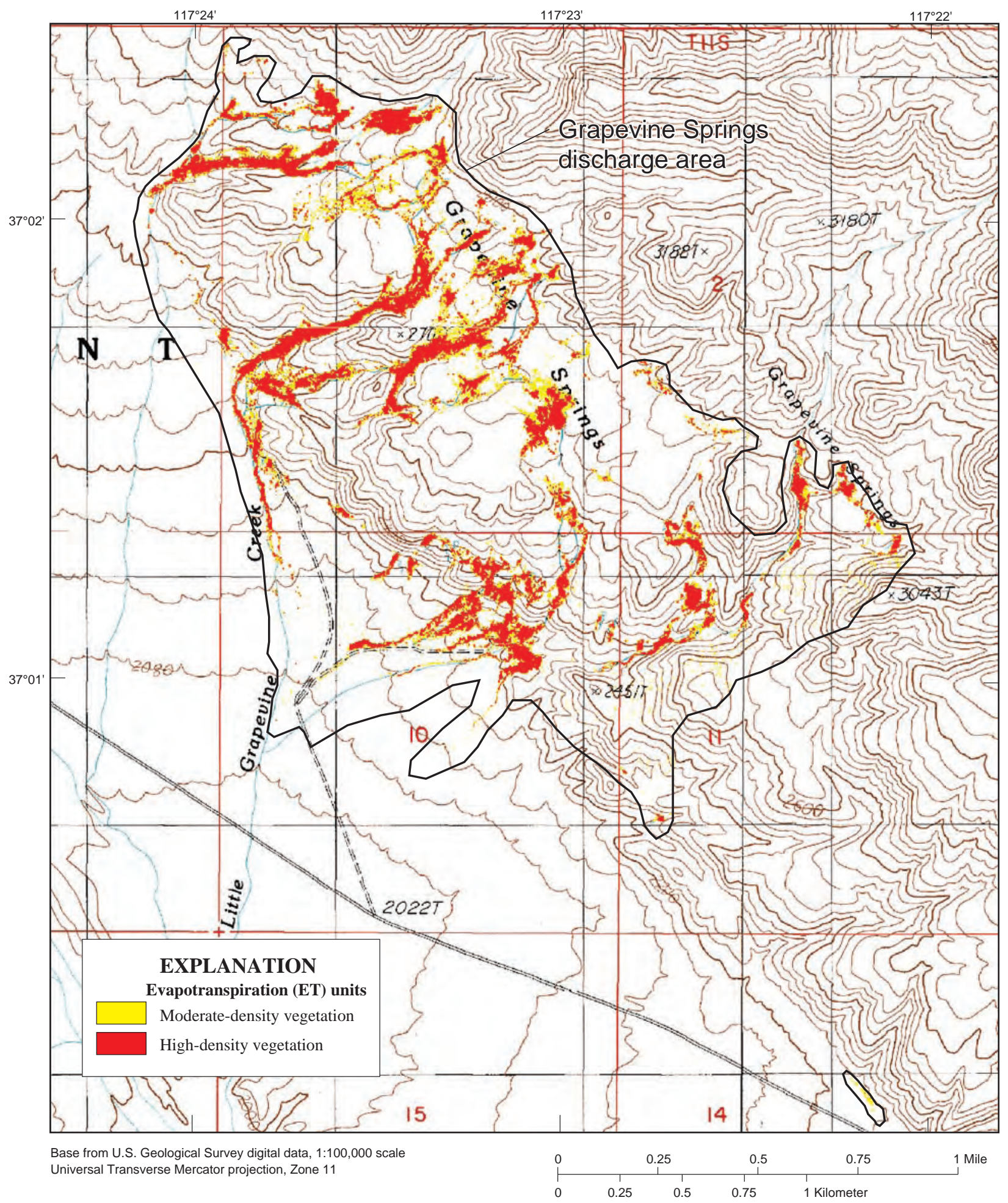

Figure 7. Distribution of ET units within Grapevine Springs discharge area that were delineated using a modified soil-adjusted vegetation index. ET-unit acreage given in table 4. 


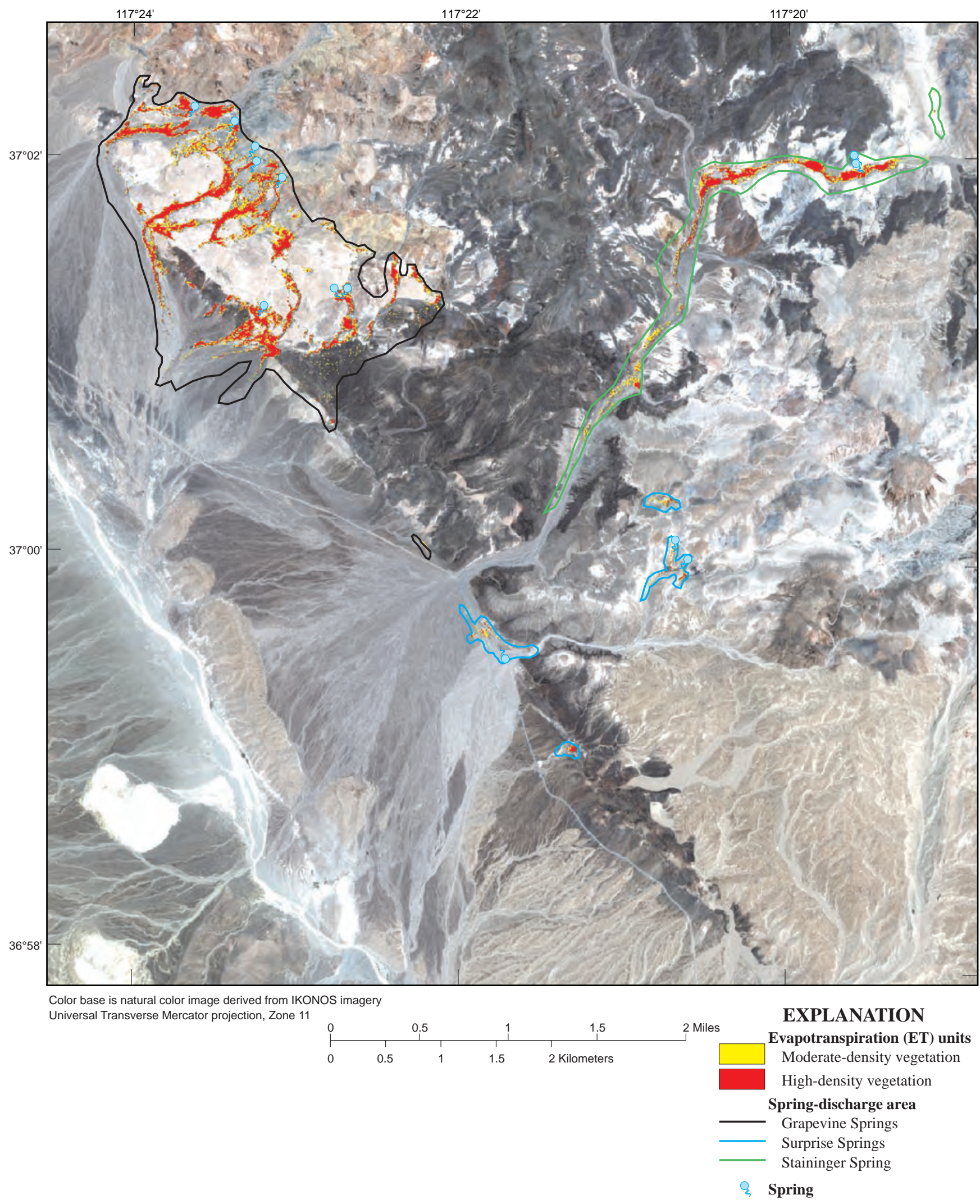

Figure 8. Distribution of ET units in major spring-discharge areas of the Grapevine Springs imagery that were delineated using a modified soil-adjusted vegetation index. ET-unit acreage listed in table 4. 


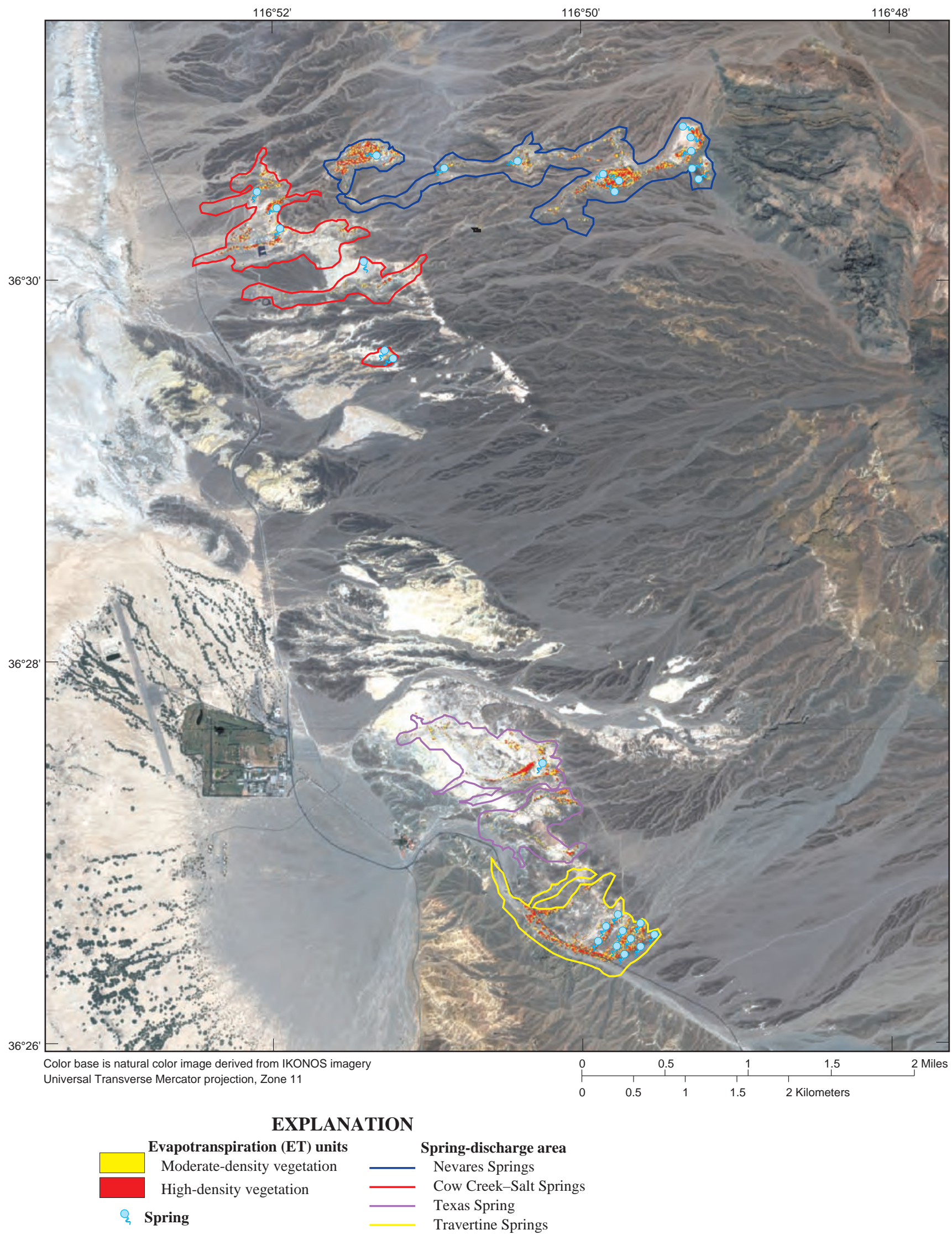

Figure 9. Distribution of ET units in major spring-discharge areas of the Furnace Creek imagery that were delineated using a modified soil-adjusted vegetation index. ET-unit acreage listed in table 5. 

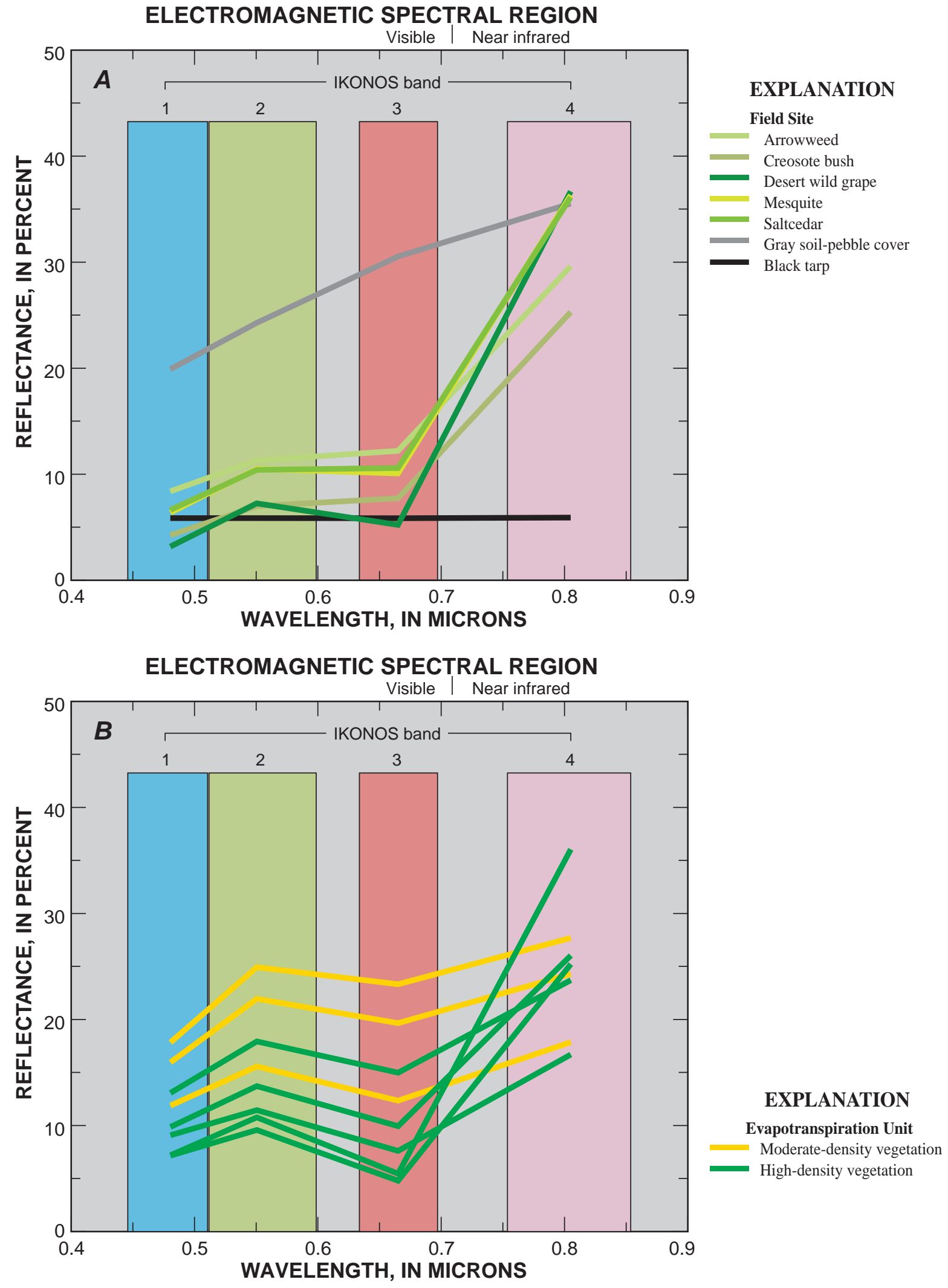

Figure 10. Spectral signatures from the IKONOS imagery used to classify ET units within the Grapevine Springs discharge area. $(A)$ Spectral signatures derived from field-spectra measurements for equivalent IKONOS bands. (B) Unique vegetation signatures developed from spectral bands 1, 2, 3, and 4. 


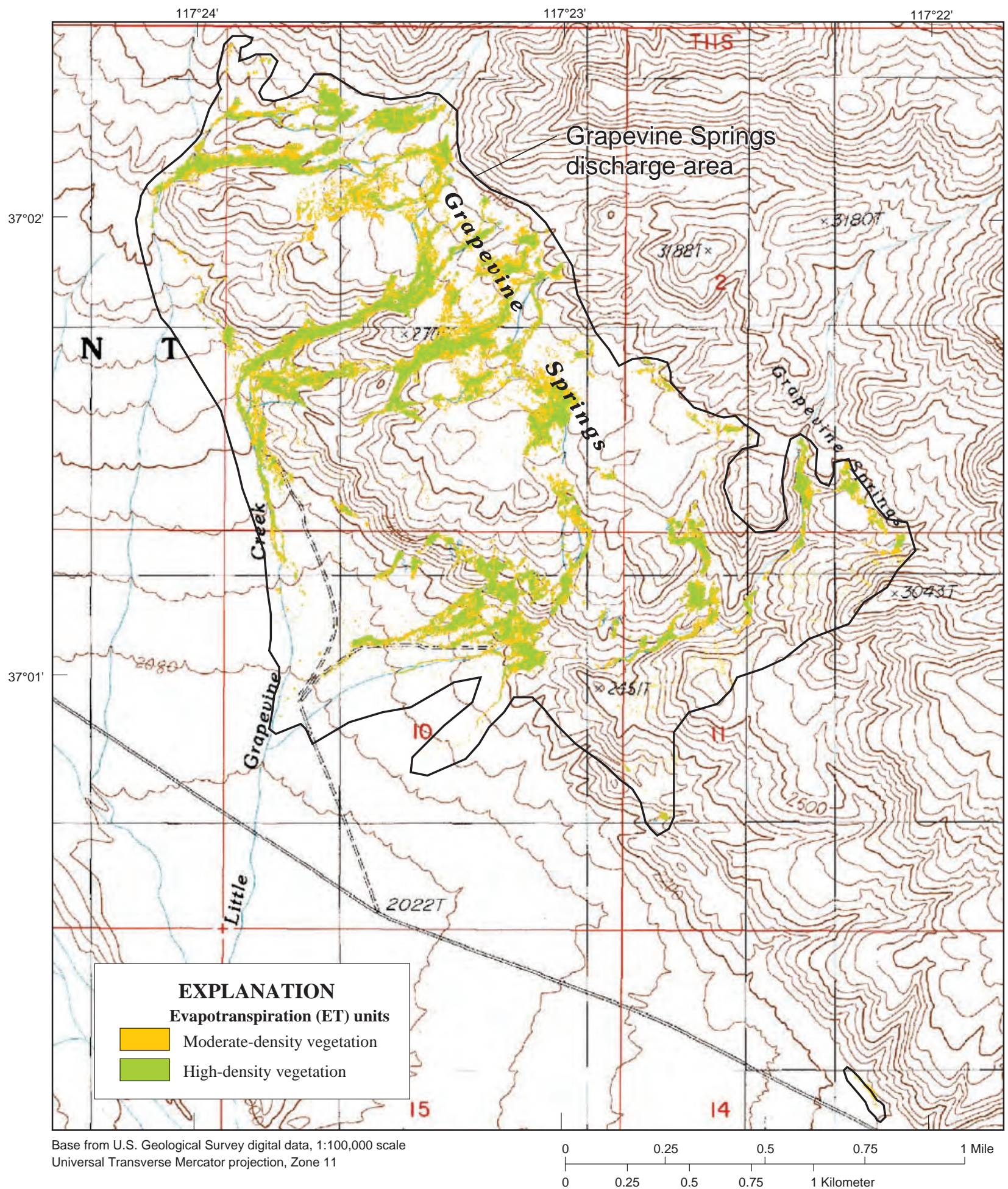

Figure 11. Distribution of ET units that were delineated by land-cover classification in the Grapevine Springs discharge area. ET-unit acreage listed in table 6. 
ET-unit acreage delineated by land-cover classification (table 7) was significantly less than that delineated by MSAVI (table 5) for major discharge areas in the Furnace Creek imagery, where differences in acreage between the two methods were as much as 50 percent. Comparison of ET-unit distributions with high-resolution images and aerial photographs indicate that MSAVI delineations more accurately portray actual vegetation conditions in the major discharge areas of the Furnace Creek imagery than delineations by land classification. Inaccuracies in the ET-unit delineations by landcover classification are presumed to be a consequence of using spectral signatures developed from the Grapevine Springs area rather than from the Furnace Creek area.

\section{Evapotranspiration Rates}

The rate at which water is evaporated into the atmosphere through the dual processes of evaporation and transpiration is referred to as the evapotranspiration or ET rate. In a groundwater discharge area, the ET rate depends on the availability of ground water and conditions specific to the area's vegetation and soil. One site was selected in the Grapevine Springs discharge area to collect data from which an annual ET rate could be calculated. The site was selected specifically to develop an estimate of annual ET representative of the dense vegetation most typical of these spring-fed riparian areas. An ET rate given by DeMeo and others (2003) in their study of ground-water discharge from the floor of Death Valley was used to represent the ET rate of moderate-density vegetation.

\section{Evapotranspiration and Surface-Flow Sites}

The Grapevine Spring ET site was in an area of dense vegetation dominated by desert wild grape (Vitis girdiana; figs. 12 and 13). Desert wild grape currently grows in the Grapevine Springs and Staininger Spring areas (fig. 6), and in a few other small discharge areas in the Death Valley area. Prior to springflow diversions for local water supply at Furnace Creek Ranch, desert wild grape was known to have grown in channels draining the regional springs in the Furnace Creek area.

Vegetation at the Grapevine Springs ET site is typical of the dense riparian vegetation throughout the area. Vegetation averages about $5 \mathrm{ft}$ in height with an occasional large tree protruding from the regional canopy. Other phreatophytic vegetation present near the site in less abundance includes sparse arrowweed, mesquite, and desert willow. A narrow band of saltgrass and yerba mansa grows along the outer fringe of the dense vegetation. As determined from spectral analysis, the site is typical of the dense riparian habitat throughout the region. The ET site is on a slightly southwest sloping surface about 350 ft east of Scotty's Ranch house (ig. 12; table 8).
The ET site was instrumented to collect the micrometeorological data needed to compute ET using the Bowen ratio (Bowen, 1926) to solve the energy budget. Instrumentation included paired temperature and humidity probes, multiple soil heat-flux plates, multiple soiltemperature probes, and a net radiometer (fig. 13; table 9). The paired temperature and humidity probes provide the data used to calculate temperature and vapor pressure gradients above the canopy. The two probes are separated by about $3.3 \mathrm{ft}$ with the lowermost probe set about a $1.5 \mathrm{ft}$ above average canopy height. The site also included a pressure sensor that was set in a shallow water-table well to acquire information to calculate daily and annual water-level fluctuations. A wind speed and direction sensor and a bulk rain gage also were installed to provide supporting climate data. Climate measurements were averaged and recorded over 20-minute intervals. Ground-water levels were measured and recorded hourly. Bulk precipitation was measured and recorded only during near-monthly field visits.

Table 7. Acreage of ET units in major spring-discharge areas of the Furnace Creek imagery delineated by land-cover classification.

[Spring-discharge areas shown in figure 9]

\begin{tabular}{|c|c|c|c|}
\hline \multirow{2}{*}{$\begin{array}{l}\text { Spring- } \\
\text { discharge } \\
\text { area }\end{array}$} & \multicolumn{3}{|c|}{ ET-unit acreage, in acres } \\
\hline & $\begin{array}{l}\text { Moderate } \\
\text { density }\end{array}$ & $\begin{array}{c}\text { High } \\
\text { density }\end{array}$ & Total \\
\hline Nevares Springs & 14.6 & 7.4 & 22 \\
\hline Cow Creek-Salt Springs & 4.8 & 2.7 & 7.5 \\
\hline Texas Spring & 4.4 & 3.1 & 7.5 \\
\hline Travertine Springs & 10.2 & 6.6 & 16.8 \\
\hline Total & 34.0 & 19.8 & 53.8 \\
\hline
\end{tabular}

Table 8. Location of data-collection sites in Grapevine Springs area.

[Site locations shown in figure 12]

\begin{tabular}{llll}
\hline \multicolumn{1}{c}{ Site name } & \multicolumn{1}{c}{$\begin{array}{c}\text { Site } \\
\text { descriptor }\end{array}$} & \multicolumn{1}{c}{ Latitude } & Longitude \\
\hline ET site & GVET & $37^{\circ} 01^{\prime} 05.7^{\prime \prime}$ & $117^{\circ} 23^{\prime} 06.4^{\prime \prime}$ \\
Surface-flow site 1 & GVSF-1 & $37^{\circ} 01^{\prime} 04.3^{\prime \prime}$ & $117^{\circ} 23^{\prime} 23.7^{\prime \prime}$ \\
Surface-flow site 2 & GVSF-2 & $37^{\circ} 01^{\prime} 02.2^{\prime \prime}$ & $117^{\circ} 23^{\prime} 17.9^{\prime \prime}$ \\
\hline
\end{tabular}




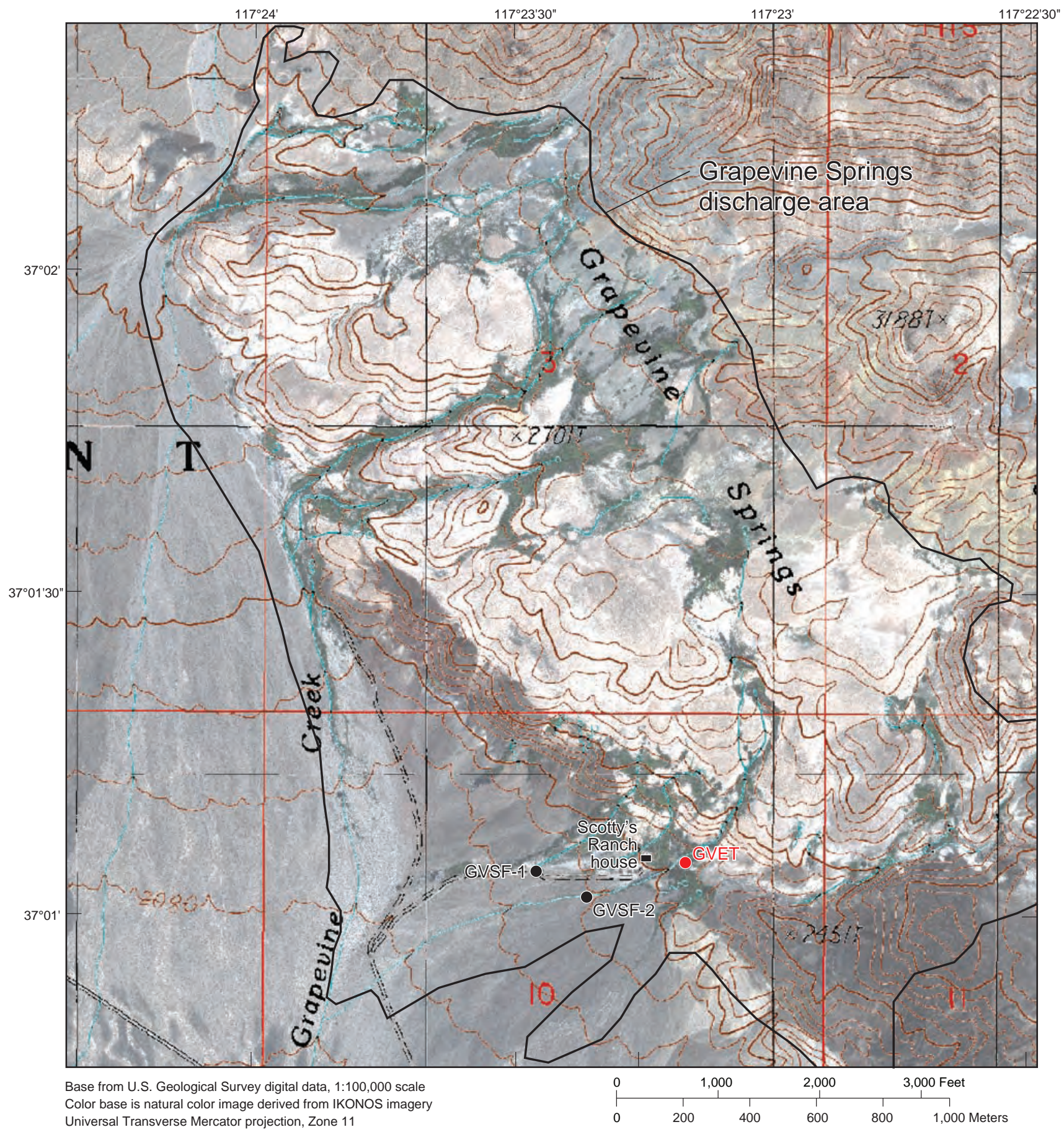

EXPLANATION

- Evapotranspiration (ET) site-Label is site name

- Surface-water measurement site—Label is site name

Figure 12. Data-collection sites in Grapevine Springs discharge area. 

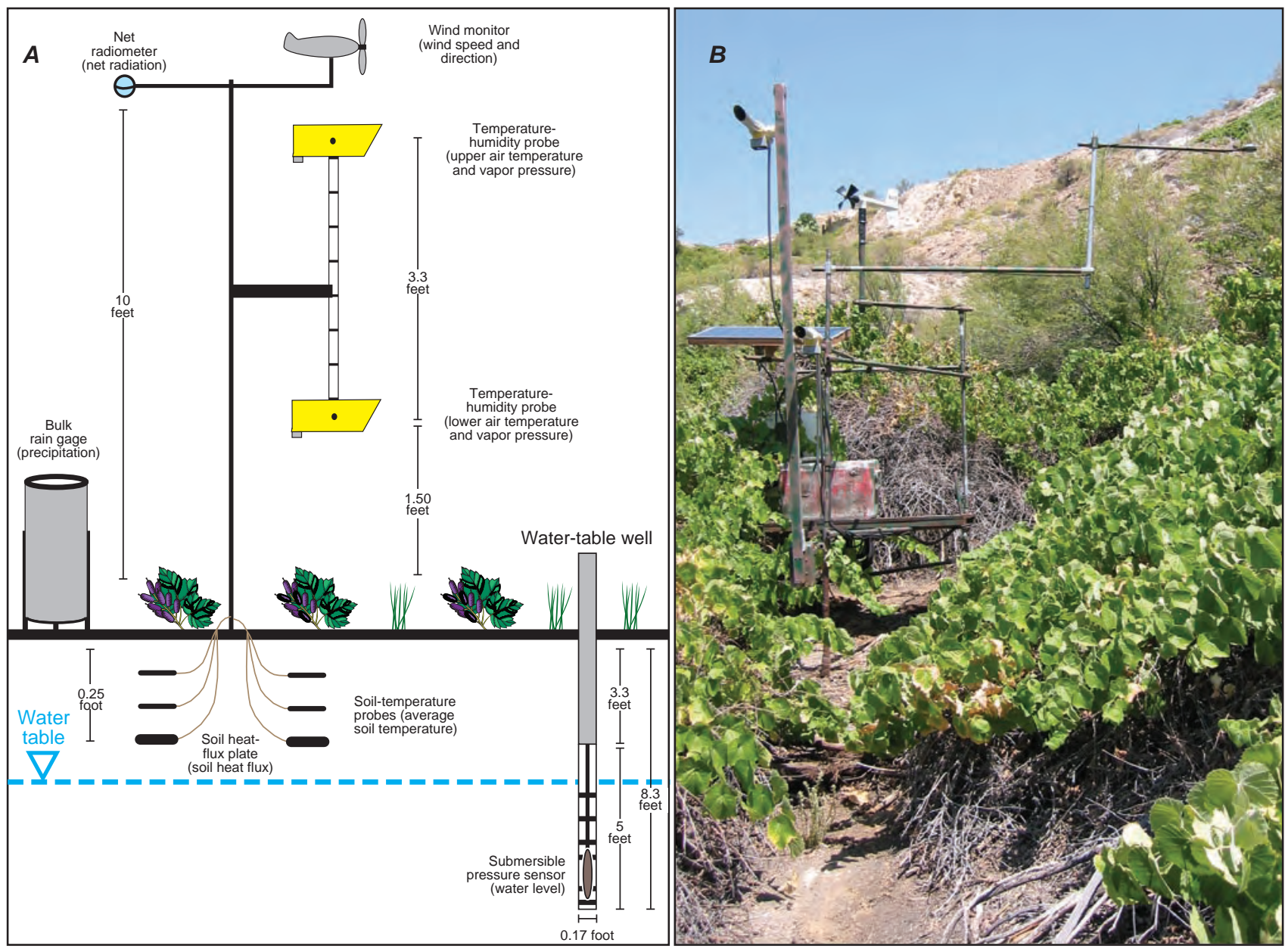

Figure 13. Instrumentation at Grapevine Springs ET site. $(A)$ schematic diagramming instrumentation and $(B)$ photograph of site.

Table 9. List of equipment used to instrument Grapevine Springs ET site.

[CSI, Campbell Scientific, Inc.; REBS, Radiation and Energy Balance Systems; DAA, Design Analysis Associates, Inc. See figure 13 for schematic of instrument configuration and setup]

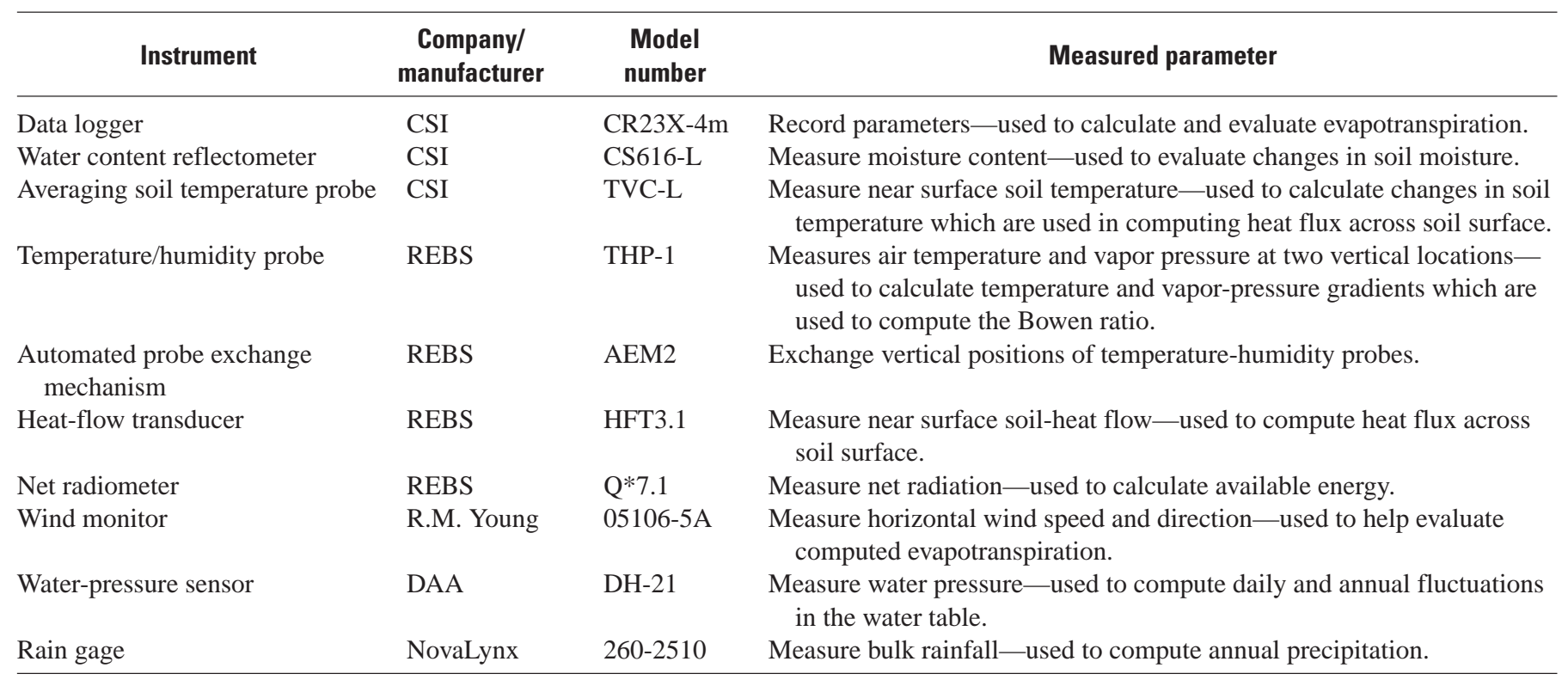


The ET site was located specifically to allow yearround access and adequate fetch. Fetch refers to a generally homogeneous area of vegetation upwind of the instrumentation. In general, fetch should be at least 100 times the distance between the uppermost instrument and the surface of the vegetation. Although ET sites typically are set up at locations having a flat lying ground surface, a slight (less than 5 percent) southwest slope exists at the Grapevine Springs ET site. The slightly sloping ground surface is mitigated by the height of the vegetation, which forms a more flat surface along the vegetation-air interface. Two surface-water-flow measurement sites also were established west of Scotty's Ranch house and downslope of the ET site (fig. 12). These sites were along two primary channels draining nearby springs and seeps. Flow measurements were made during ET site visits using a portable Parshall flume.
Data collection at the Grapevine Springs ET site started September 27, 2000, and ended November 4, 2002. A typical, 50 -day period of recorded values is shown in figure 14. Daily minimum, average, and maximum values computed from the 20-minute measurements are shown for the entire period of record in figure 15 . Precipitation, water-level, and surfacewater-discharge measurements also were collected during the study to better evaluate the temporal changes in computed ET (fig. 16; tables 10-12). All data collected during the study are available from the U.S. Geological Survey, Henderson, Nevada.

Precipitation data (fig. 16; table 12) indicate that about 90 percent of the rainfall occurred during the first one-half of the approximately 2 -year study period. Trends in the groundwater level, surface-water discharge, air temperature, and humidity (figs. 15 and 16) all indicate a response to the higher
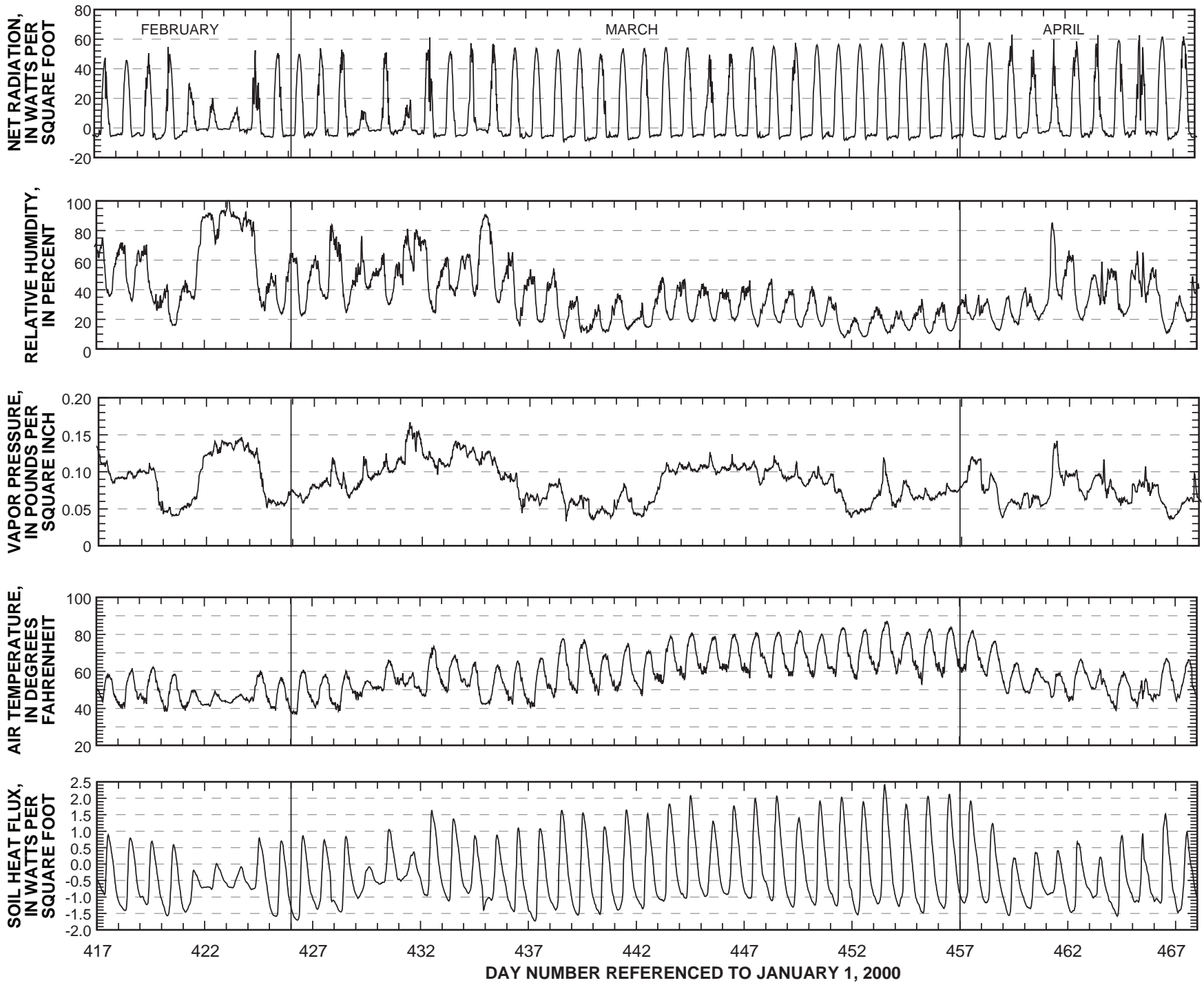

Figure 14. Micrometeorological data collected at Grapevine Springs ET site, February 20-April 11, 2001 (day numbers 417 and 467, respectively). 

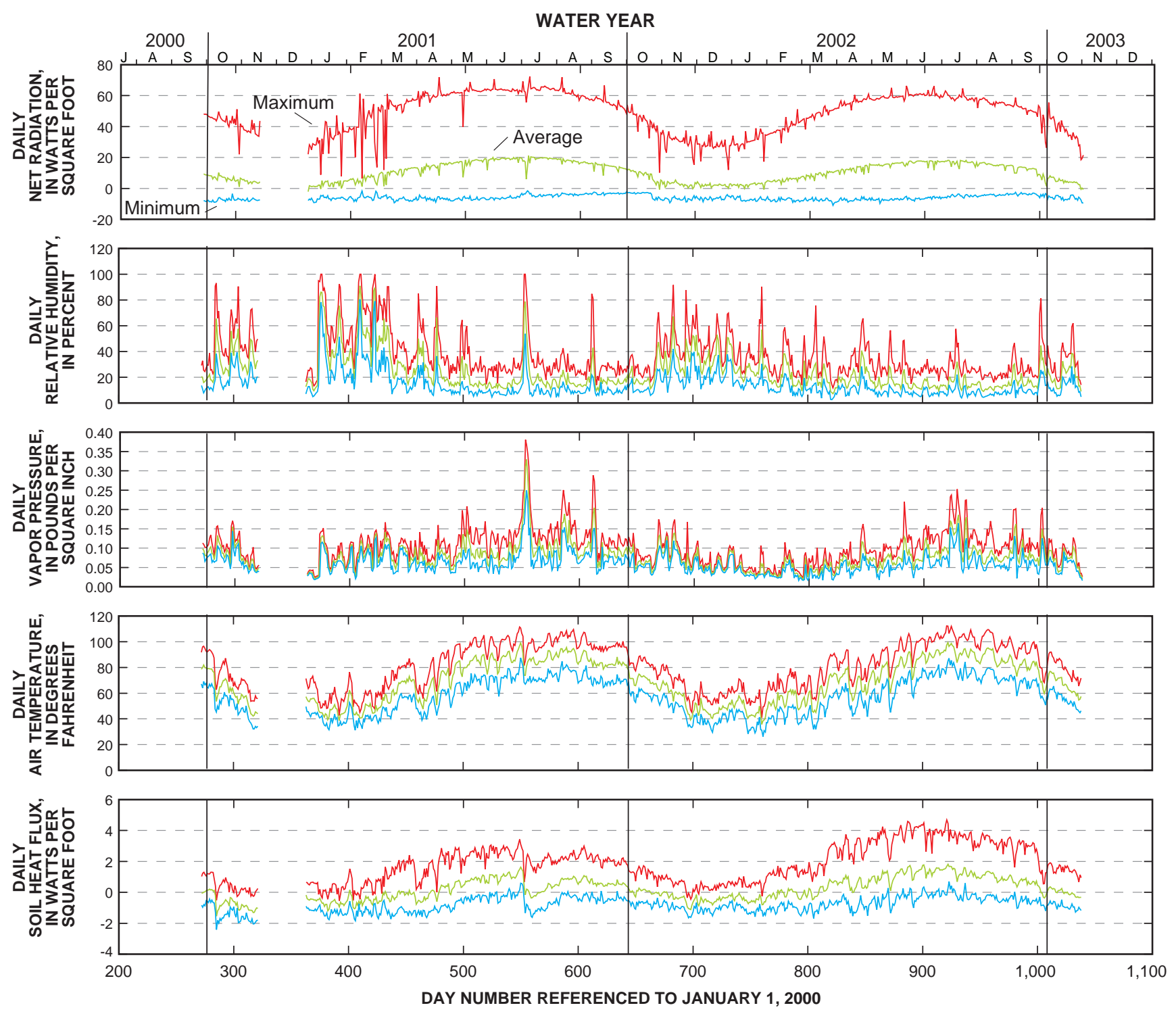

Figure 15. Daily minimum, average, and maximum of recorded micrometeorologic measurements collected at Grapevine Springs ET site, September 28, 2000-November 3, 2002 (day numbers 272 and 1,038, respectively).

precipitation period. Ground-water levels (fig. 16; table 10) indicate about $1.2 \mathrm{ft}$ of annual fluctuation and generally were a few tenths of a foot higher in water year 2001 than in 2002. These slightly higher water levels are attributed to greater precipitation.

Surface-water discharge data (figs. 12 and 16; table 11) indicate differences within and between sites. Measured discharge at GVSF-2 generally was higher than that measured at GVSF-1. The largest annual fluctuation in measured discharge was at GVSF-2 in water year 2001, where discharges ranged from about $25 \mathrm{gal} / \mathrm{min}$ in late winter to less than $1 \mathrm{gal} / \mathrm{min}$ in late summer (table 11). In water year 2002, the annual discharge fluctuation at GVSF-2 was less, with discharges ranging about $16 \mathrm{gal} / \mathrm{min}$ in late winter to about $3 \mathrm{gal} / \mathrm{min}$ in late summer. Surface-water discharge at GVSF-1 ranged from about $12 \mathrm{gal} / \mathrm{min}$ in late winter to about $2 \mathrm{gal} / \mathrm{min}$ in later summer and exhibited less annual fluctuation and a more consistent fluctuation between years. The decrease in surface-water discharge during spring and summer is attributed to increasing evapotranspiration by local riparian vegetation. The increased discharge, particularly at GVSF-2, in the winter of the water year 2001 is attributed to local runoff associated with higher precipitation. 

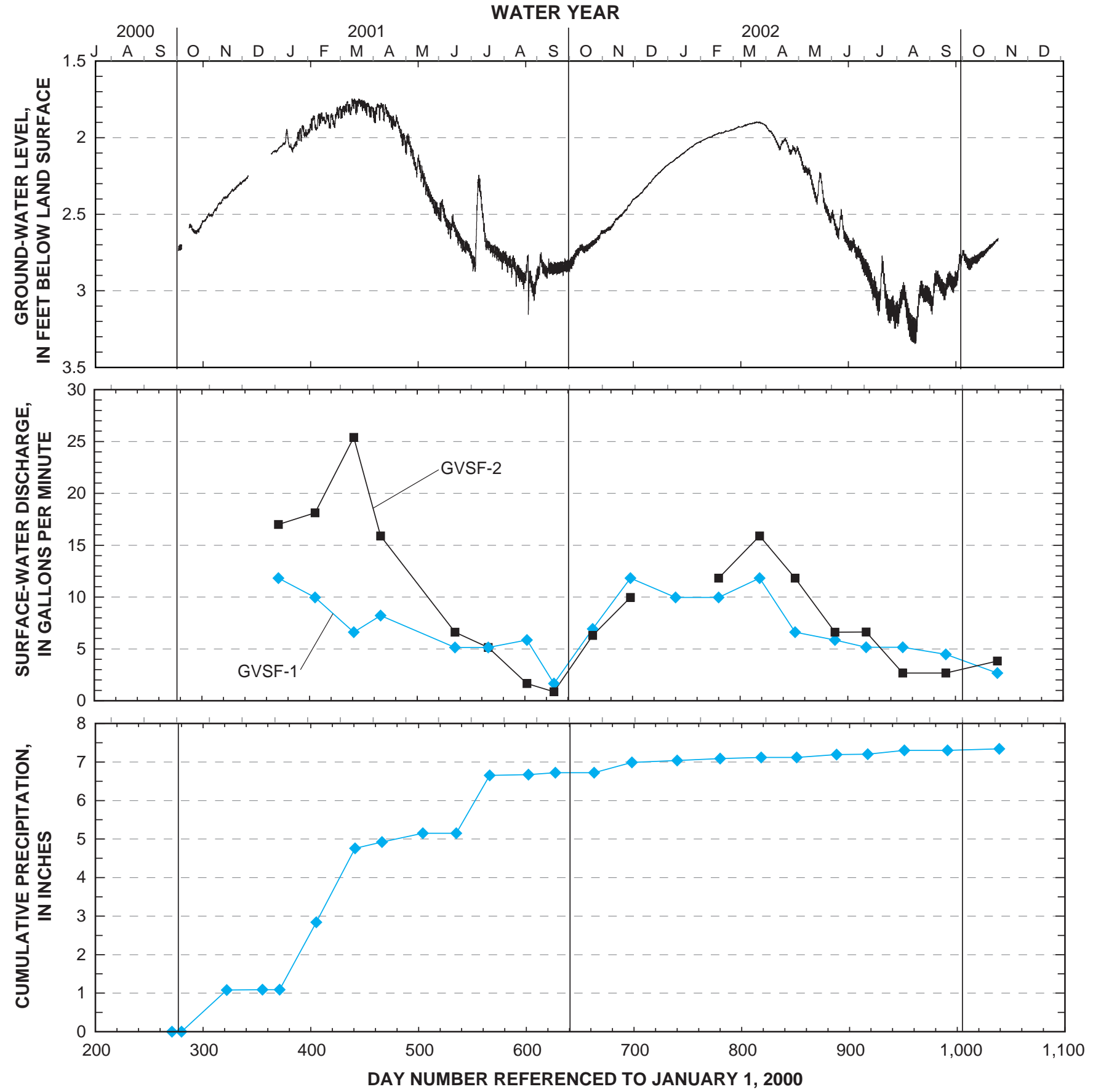

Figure 16. Continual ground-water-level, periodic channel-discharge, and precipitation measurements taken at or near Grapevine Springs ET site, September 27, 2000-November 4, 2002 (day numbers 271 and 1,039, respectively). 
Table 10. Periodic water levels measured in shallow well at Grapevine Springs ET site.

[USGS well site identification number is 370106117230601 . Measuring point of well is 1.4 feet above land surface. Altitude of land surface at well is 2,230 feet above land surface. PST, Pacific Standard Time; PDT, Pacific Daylight Time]

\begin{tabular}{|c|c|c|}
\hline $\begin{array}{l}\text { Measurement } \\
\text { date }\end{array}$ & $\begin{array}{l}\text { Measurement } \\
\text { time }\end{array}$ & $\begin{array}{l}\text { Water level, in } \\
\text { feet below } \\
\text { land surface }\end{array}$ \\
\hline 01/05/2001 & 11:25 (PST) & 2.03 \\
\hline 02/08/2001 & 11:40 (PST) & 1.91 \\
\hline 03/16/2001 & 10:54 (PST) & 1.80 \\
\hline 04/10/2001 & 10:10 (PDT) & 1.82 \\
\hline 05/18/2001 & 9:55 (PDT) & 2.28 \\
\hline 06/18/2001 & 12:53 (PDT) & 2.64 \\
\hline 07/19/2001 & 10:32 (PDT) & 2.75 \\
\hline 08/24/2001 & 10:07 (PDT) & 2.83 \\
\hline 09/18/2001 & 9:42 (PDT) & 2.80 \\
\hline $10 / 24 / 2001$ & 10:35 (PDT) & 2.68 \\
\hline $11 / 28 / 2001$ & 10:58 (PST) & 2.40 \\
\hline 01/09/2002 & 9:32 (PST) & 2.12 \\
\hline $02 / 18 / 2002$ & $8: 33$ (PST) & 1.95 \\
\hline 03/28/2002 & 10:33 (PST) & 1.89 \\
\hline 04/30/2002 & 10:12 (PDT) & 2.08 \\
\hline 06/06/2002 & 10:23 (PDT) & 2.55 \\
\hline 07/05/2002 & 9:25 (PDT) & 2.80 \\
\hline 08/08/2002 & $11: 25$ (PDT) & 2.91 \\
\hline 09/17/2002 & 12:02 (PDT) & 2.91 \\
\hline
\end{tabular}

\section{Computed Energy-Budget Fluxes and Evapotranspiration}

ET at the Grapevine Springs ET site was computed using the Bowen ratio (Bowen, 1926) to solve the energy budget. This technique has been applied successfully to estimate ET throughout the western part of southern Nevada and the Death Valley region of California (Laczniak and others, 1999; Reiner and others, 2002; DeMeo and others, 2003). The Bowen ratio, a relation between latent and sensible heat fluxes, is used to solve the energy budget. At the Grapevine Springs ET site, the energy budget can be expressed mathematically in terms of its principle flux components as:

$$
R_{n}=H+G+\lambda E
$$

where

$R_{n}$ is net radiation (energy per area per time),

$\mathrm{H}$ is sensible heat flux (energy per area per time),

$G$ is subsurface heat flux (energy per area per time), and

$\lambda \mathrm{E}$ is latent heat flux (energy per area per time). where

$\lambda$ is latent heat of vaporization for water (energy per mass), and

$E$ is the rate of water evaporation or the mass flux of water vapor (mass per area per time).
Table 11. Periodic surface-water discharge measured near Grapevine Springs ET site.

[GVSF-1 and GVSF-2 are measurement sites. Site locations are shown in figure 12. Data are in gallons per minute. - , no measurement]

\begin{tabular}{ccc}
\hline $\begin{array}{c}\text { Measurement } \\
\text { date }\end{array}$ & \multicolumn{2}{c}{ Surface-water discharge } \\
\cline { 2 - 3 } & GVSF-1 & GVSF-2 \\
\hline $01 / 05 / 2001$ & 11.82 & 16.99 \\
$02 / 08 / 2001$ & 9.95 & 18.11 \\
$03 / 16 / 2001$ & 6.61 & 25.40 \\
$04 / 10 / 2001$ & 8.22 & 15.90 \\
$06 / 18 / 2001$ & 5.14 & 6.61 \\
$07 / 19 / 2001$ & 5.14 & 5.14 \\
$08 / 24 / 2001$ & 5.86 & 1.66 \\
$09 / 18 / 2001$ & 1.66 & 0.86 \\
$10 / 24 / 2001$ & 6.92 & 6.31 \\
$11 / 28 / 2001$ & 11.82 & 9.95 \\
$01 / 09 / 2002$ & 9.95 & - \\
$02 / 18 / 2002$ & 9.95 & 11.82 \\
$03 / 28 / 2002$ & 11.82 & 15.90 \\
$04 / 30 / 2002$ & 6.61 & 11.82 \\
$06 / 06 / 2002$ & 5.86 & 6.61 \\
$07 / 05 / 2002$ & 5.15 & 6.62 \\
$08 / 08 / 2002$ & 5.15 & 2.66 \\
$09 / 17 / 2002$ & 4.47 & 2.66 \\
$11 / 04 / 2002$ & 2.66 & 3.83 \\
\hline
\end{tabular}

The Bowen ratio, $\mathrm{H} / \lambda \mathrm{E}$, can be computed by multiplying the ratio between the measured temperature and vapor pressure gradients by the psychometric constant as:

$$
\mathrm{H} / \lambda \mathrm{E}=\gamma_{\mathrm{c}}\left[\left(\mathrm{T}_{1}-\mathrm{T}_{\mathrm{u}}\right) /\left(\mathrm{e}_{\mathrm{P}}-\mathrm{e}_{\mathrm{u}}\right)\right],
$$

where

$T_{I, u}$ is temperature at lower or upper reference point,

$\Theta_{, u} \mathrm{u}$ is vapor pressure at lower or upper reference point, (force per area), and

$\gamma_{C}$ is the psychometric constant (presure per temperature).

Latent heat then can be calculated by substituting the Bowen ratio into a rearranged form of the energy-budget equation as:

$$
\lambda E=\left(R_{n}-G\right) /\left\{\gamma_{C}\left[\left(T_{l}-T_{u}\right) /\left(\Theta-e_{u}\right)\right]+l\right\},
$$

Some conditions exist for which the Bowen ratio becomes unstable, such as when the Bowen ratio approaches -1 . Under these conditions, the equation describing latent heat as a function of the Bowen ratio approaches infinity. During these infrequent periods, latent heat was set using a filtering algorithm that estimates the Bowen ratio based on preceding and following values. This and other potential errors associated with applying the Bowen ratio to solve the energy 
Table 12. Periodic bulk precipitation measured at Grapevine Springs ET site.

[Site locations are shown in figure 12. Data are in inches]

\begin{tabular}{|c|c|c|c|}
\hline \multirow{2}{*}{$\begin{array}{l}\text { Measurement } \\
\text { date }\end{array}$} & \multicolumn{3}{|c|}{ Precipitation } \\
\hline & Period & $\begin{array}{c}\text { Cumulative } \\
\text { total }\end{array}$ & $\begin{array}{c}\text { Cumulative } \\
\text { annual }\end{array}$ \\
\hline 09/27/2000 & 0 & 0 & 0 \\
\hline $10 / 06 / 2000$ & 0 & 0 & 0 \\
\hline $11 / 17 / 2000$ & 1.08 & 1.08 & 1.08 \\
\hline $12 / 20 / 2000$ & 0.01 & 1.09 & 1.09 \\
\hline 01/05/2001 & 0 & 1.09 & 0 \\
\hline 02/08/2001 & 1.75 & 2.84 & 1.75 \\
\hline 03/16/2001 & 1.92 & 4.76 & 3.67 \\
\hline 04/10/2001 & 0.16 & 4.92 & 3.83 \\
\hline 05/18/2001 & 0.23 & 5.15 & 4.06 \\
\hline 06/18/2001 & 0 & 5.15 & 4.06 \\
\hline 07/19/2001 & 1.5 & 6.65 & 5.56 \\
\hline 08/24/2001 & 0.02 & 6.67 & 5.58 \\
\hline 09/18/2001 & 0.05 & 6.72 & 5.63 \\
\hline $10 / 24 / 2001$ & 0 & 6.72 & 5.63 \\
\hline $11 / 28 / 2001$ & 0.27 & 6.99 & 5.9 \\
\hline 01/09/2002 & 0.05 & 7.04 & 0 \\
\hline $02 / 18 / 2002$ & 0.05 & 7.09 & 0.05 \\
\hline 03/28/2002 & 0.03 & 7.12 & 0.08 \\
\hline 04/30/2002 & 0 & 7.12 & 0.08 \\
\hline 06/06/2002 & 0.07 & 7.19 & 0.15 \\
\hline 07/05/2002 & 0.01 & 7.2 & 0.16 \\
\hline 08/08/2002 & 0.1 & 7.3 & 0.26 \\
\hline $09 / 17 / 2002$ & 0 & 7.3 & 0.26 \\
\hline $11 / 04 / 2002$ & 0.04 & 7.34 & 0.30 \\
\hline
\end{tabular}

budget can be found in many standard texts and in a paper by Ohmura (1982). A more detailed description of the Bowen ratio solution and its associated instrumentation is given in Laczniak and others (1999).

Latent and sensible heat fluxes were calculated from 20-minute micrometeorologic and flux measurements made at the Grapevine Springs ET site. Computed and measured 20-minute, energy-budget fluxes for a typical 10-day period are shown in figure 17. The figure also shows ground-water levels measured over this same 10-day period. The trend in daily water level is inversely related to latent heat flux-as latent heat flux increases, about mid-morning, water levels start declining.

ET, defined here as the amount of liquid water lost through the mass flux of water vapor associated with the latent heat flux, is calculated directly from latent heat flux using the equation:

$$
E T=\lambda E /\left(\lambda \rho_{W}\right)
$$

where

ET is evaporation (length per time),

$\rho_{\mathrm{W}}$ is the density of water (mass per volume), and

$\lambda \mathrm{E}$ is latent heat flux (energy per unit area per time).

Calculated daily ET and mean daily ground-water level are shown in figure 18, and monthly values are shown in figure 19 for the entire study period. Monthly ET shows an inverse relation to water level similar to that shown by daily values of ET and water level-as ET begins to increase in April, water levels begin to decline, and when ET decreases in September, water levels rise. The slightly greater ET and higher water levels in water year 2001 compared to 2002 are likely a consequence of greater precipitation during water year 2001.

Daily ET begins increasing in late spring and peaks in the early through mid-summer period (June and July; figs. 18 and 19). During this peak period, daily ET ranged from about 0.18 to 0.25 in., and monthly ET ranged from about 5.7 to $6.2 \mathrm{in}$. ET totaled about $2.7 \mathrm{ft}$ in water year 2001 (Oct. 2000-Sept. 2001) and totaled about $2.3 \mathrm{ft}$ in water year 2002 (Oct. 2001-Sept. 2002; figs. 18 and_19). The greater ET in water year 2001 is attributed to the greater precipitation. The approximate difference in precipitation between the two water years (fig. 16; table 12) is about $0.6 \mathrm{ft}$ or only about $0.2 \mathrm{ft}$ more than the difference in computed ET.

The daily ground-water-level fluctuation varied from near zero in the mid-winter months to a maximum of about 2.3 in. in the mid- and late-summer months (fig. 20). During the active ET period (late spring through summer; fig. 19), the daily change in ground-water level greatly exceeded measured ET (fig. 20). The specific yield is defined as the volume of water a unit volume of saturated permeable rock releases when drained by gravity. Thus, the specific yield can be calculated by dividing the volume of water released by the ground-waterlevel change. Assuming that the measured daily change in water level is a response solely to computed daily ET, the specific yield of the saturated sediment tapped by the local vegetation at the Grapevine Springs ET site can be calculated as the daily ET divided by the daily change in ground-water level. This approach assumes that any water replacing that removed by ET from the saturated sediment is minimal. Because this assumption may not be entirely accurate, the specific yield calculated by this method is referred to as apparent. The apparent specific yield for the active ET period (daily ET greater than 0.025 in.) during water year 2002 ranges from about 0.08 to $0.26 \mathrm{in}$. (fig. 20). The daily change in water level likely is moderated by water flowing laterally from adjacent areas to replace that removed by ET. Because lateral inflow lessens the magnitude of the daily groundwater-level change, the apparent specific yield is presumed to be a maximum value. Although the apparent specific yield is inexact, it does fall within the range expected for the clayey sand and sandy clay present at the water table. Moreover, the similarity in trends between daily ET and daily changes in the ground-water level indicate that ET likely is the primary process affecting the water table. 


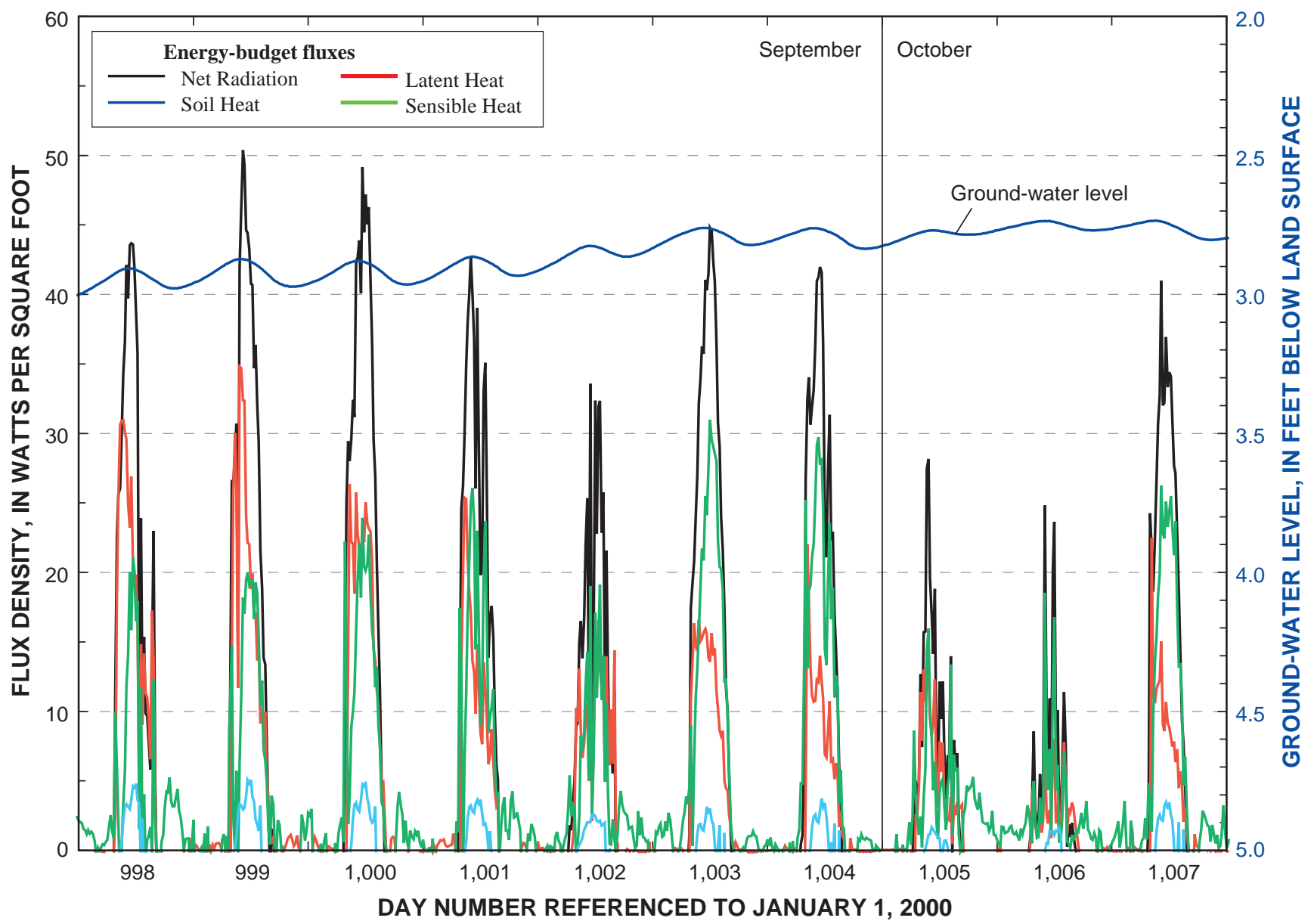

Figure 17. Computed and measured energy-budget fluxes and measured ground-water level at Grapevine Springs ET site, September 24-0ctober 3, 2003 (day numbers 998 and 1,007, respectively).

\section{Mean Annual Ground-Water Discharge by Evapotranspiration}

Regional ground-water discharge in the study area occurs primarily as springflow and seepflow. Quantifying regional discharge by totaling springflow and seepflow in each discharge area is difficult because flows seldom are directed into measurable channels, and many of the springs and seeps are small and hidden by a dense cover of vegetation. Alternatively, in areas where a significant amount of discharge evaporates or infiltrates into the shallow water-table aquifer and later is transpired by the local riparian vegetation, groundwater discharge can be estimated accurately from ET.

The volume of ET that occurs over a specific surface is the product of the surface area that contributes to ET and the average ET rate at the surface during the period of interest. Accordingly, mean annual ET from a discharge area can be estimated knowing the rate of annual ET and acreages of the different vegetation present in the discharge area. Because measured ET rates are inclusive of water that originates from sources such as precipitation or surface inflow, any contribution from sources other than ground water must be removed prior to estimating ground-water discharge from ET.
The mean annual discharge of ground water by ET from each major spring-discharge area along the eastern margin of Death Valley was estimated by summing mean annual discharges computed for delineated units of moderate- and high-density vegetation (table 3). Annual discharge from each ET unit was calculated volumetrically as the product of its acreage (as delineated by spectral analysis; tables 4 and $\underline{6}$ ) and estimated mean annual ground-water ET rate.

Mean annual ET was calculated for high-density vegetation at the Grapevine Springs site by averaging ET computed for three different 365-day periods within the 2-year collection period (table 13). The ground-water component of ET during these three 365-day periods, calculated by subtracting measured precipitation from ET, ranged from 2.1 to $2.3 \mathrm{ft}$ and averaged $2.2 \mathrm{ft}$ (table 13). The average value, $2.2 \mathrm{ft}$, is considered a reasonable estimate of mean annual ET because the record spanned both a wet and dry year. A value of $2.0 \mathrm{ft}$ was used to represent the mean annual groundwater discharge by ET for the moderate-density ET unit. This value is taken from DeMeo and others (2003, p. 24), who determined that this rate is representative of annual ET for similar, moderate-density vegetation growing along the valley floor. 


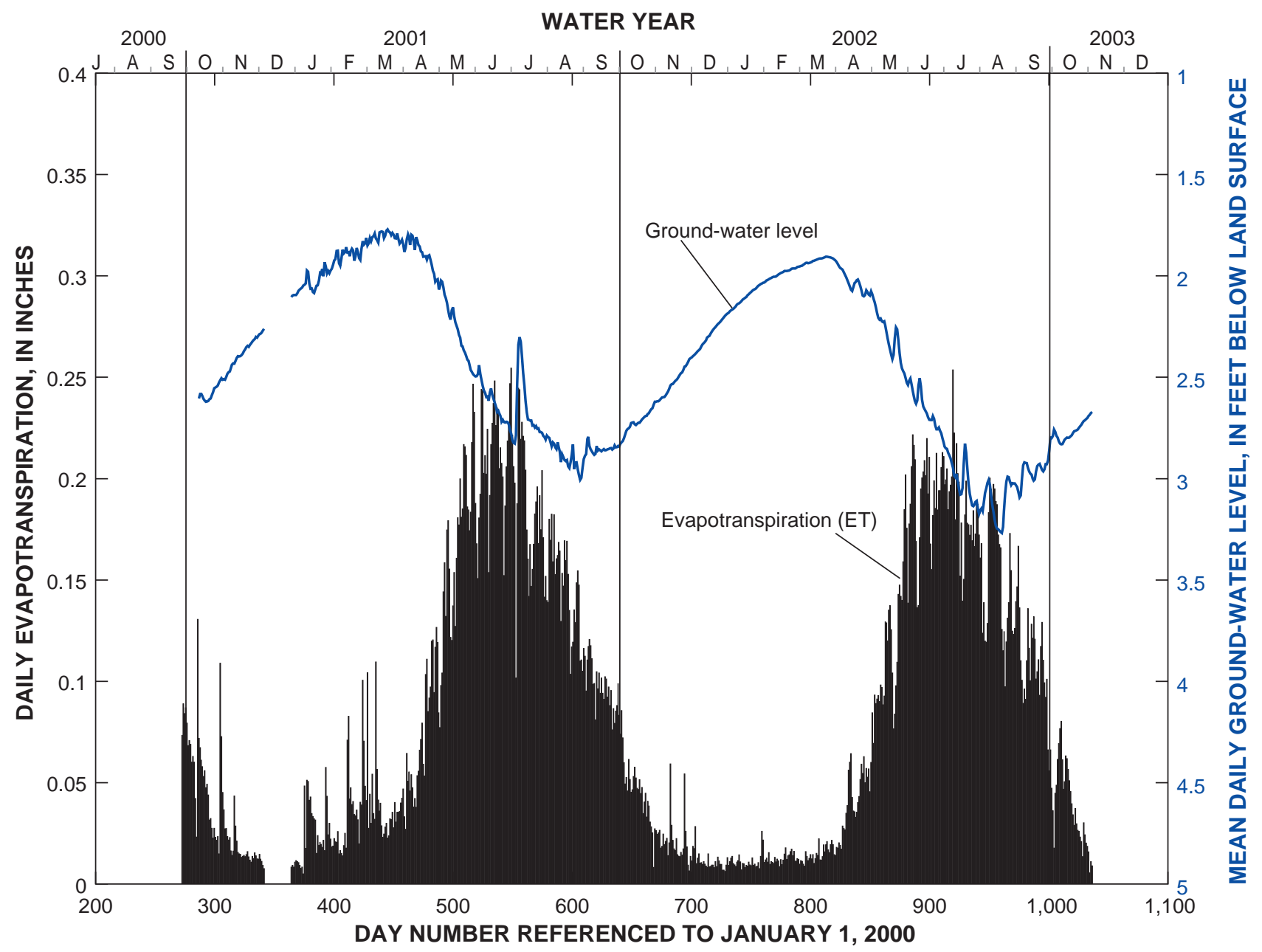

Figure 18. Daily evapotranspiration and mean daily ground-water level at Grapevine Springs ET site, September 28, 2000-November 3, 2002 (day numbers 272 and 1,038, respectively).

The mean annual discharge of ground water by ET computed for each ET unit and major spring-discharge area is listed in table 14. Volumetric discharge was calculated using acreages delineated from MSAVI analysis. MSAVI-delineated units were used because they best represented the overall distribution of the vegetation within all spring-discharge areas. Mean annual discharge for major spring-discharge areas in the Grapevine Springs imagery ranged from 9 to 405 acre-ft, and in the Furnace Creek imagery from 21 to 61 acre-ft. The Grapevine Springs discharge area has the highest estimated ground-water discharge and Surprise Spring has the least (table 14).

Estimates listed in table 14 represent ground water used by local riparian vegetation. The discharge estimate for the Grapevine Springs discharge area represents the total quantity of ground water discharged annually from the area's local springs and seeps because no water is diverted from or imported into the area. The discharge estimates also equate to the approximate ground-water requirement of the area's natural riparian vegetation. Estimating the total quantity of ground water discharged from springs and seeps in the other major spring discharge areas (Staininger, Surprise, Nevares, Cow Creek-Salt, Texas, and Travertine Springs) is complicated by local water diversions. Discharge measurements along the diversions have been inconsistent and intermittent, and the amount of water that is diverted and recycled back into the shallow flow system or applied for turf watering is uncertain. An accurate estimate of the total volume of ground water discharged from these springs and seeps requires that the estimate listed in table 14 be increased by the quantity of water diverted, and reduced by an amount equal to that estimated for vegetation maintained by watering. The acreage of only spring-fed vegetation could be calculated by carefully removing the vegetation sustained by local watering.

Estimates of ground-water discharge presented in this report are difficult to compare to published estimates because they often represent different hydrologic or environmental conditions. For example, most published estimates are based on measurements of flow in a channel that drains only a portion of the springs within the discharge area. 


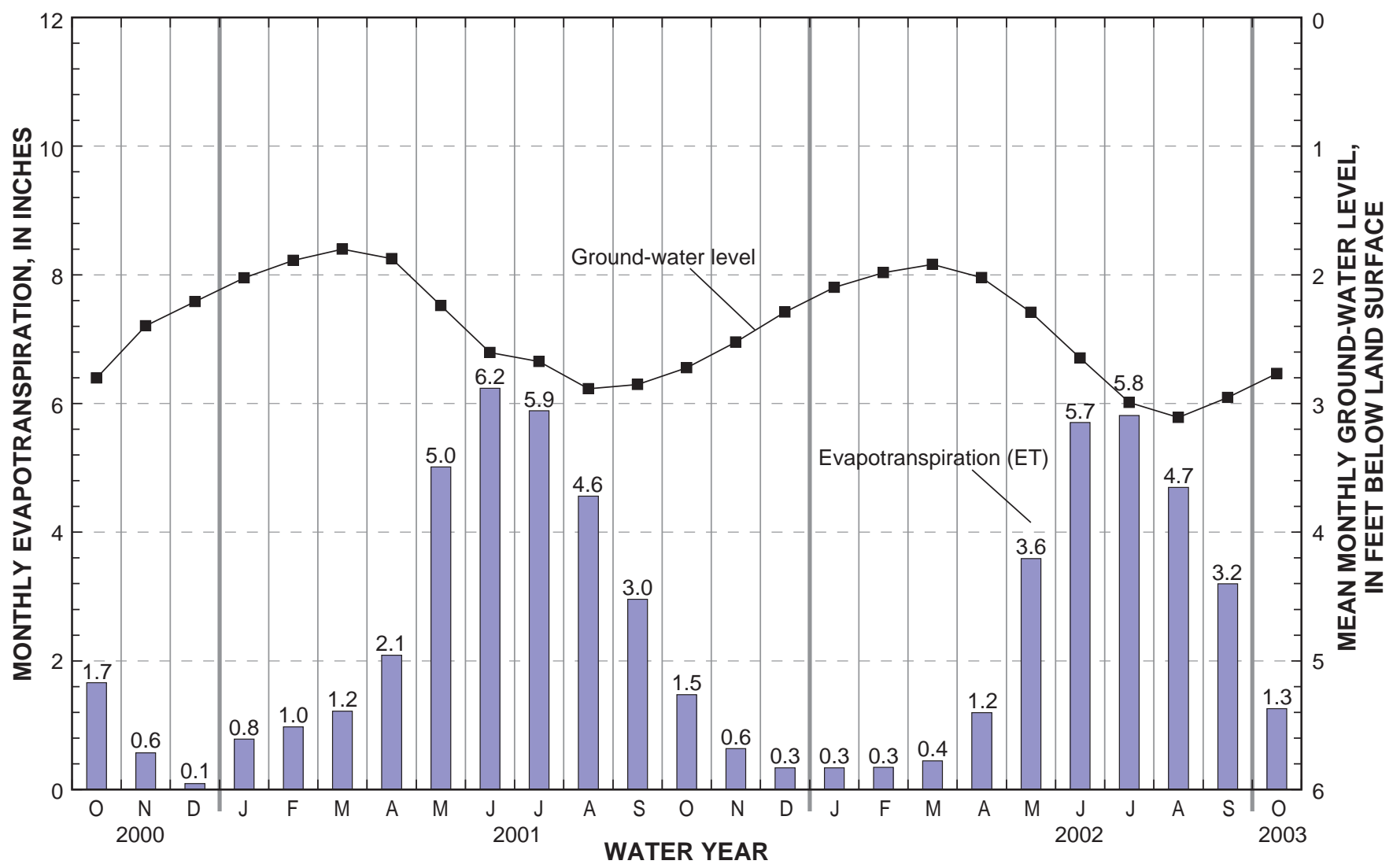

Figure 19. Monthly evapotranspiration (ET) and mean monthly ground-water level at Grapevine Springs ET site, October 2000-0ctober 2002. Number above bar is total monthly evapotranspiration, in inches.

Table 13. Evapotranspiration and ground-water evapotranspiration calculated at Grapevine Springs ET site for three different 365-day periods.

[Value given in parentheses for start day and end day is integer day referenced to January 1, 2000. ET is evapotranspiration. Ground-water ET is calculated as ET minus precipitation. Site location shown in figure 12. Daily ET shown in figure 18]

\begin{tabular}{|c|c|c|c|c|c|}
\hline \multicolumn{2}{|c|}{ 365-day period } & \multirow{2}{*}{$\begin{array}{l}\text { Precipitation, } \\
\text { in inches }\end{array}$} & \multirow{2}{*}{$\begin{array}{c}\text { ET, } \\
\text { in inches }\end{array}$} & \multicolumn{2}{|c|}{ Ground-water ET } \\
\hline Start day & End day & & & inches & feet \\
\hline 01/29/2000 (364) & 12/28/2001 (728) & 5.9 & 32.2 & 26.3 & 2.2 \\
\hline $10 / 31 / 2001(670)$ & $10 / 30 / 2002(1034)$ & 0.6 & 27.6 & 27.0 & 2.3 \\
\hline 06/28/2001 (545) & 06/27/2002 (909) & 1.6 & 27.3 & 25.7 & 2.1 \\
\hline
\end{tabular}




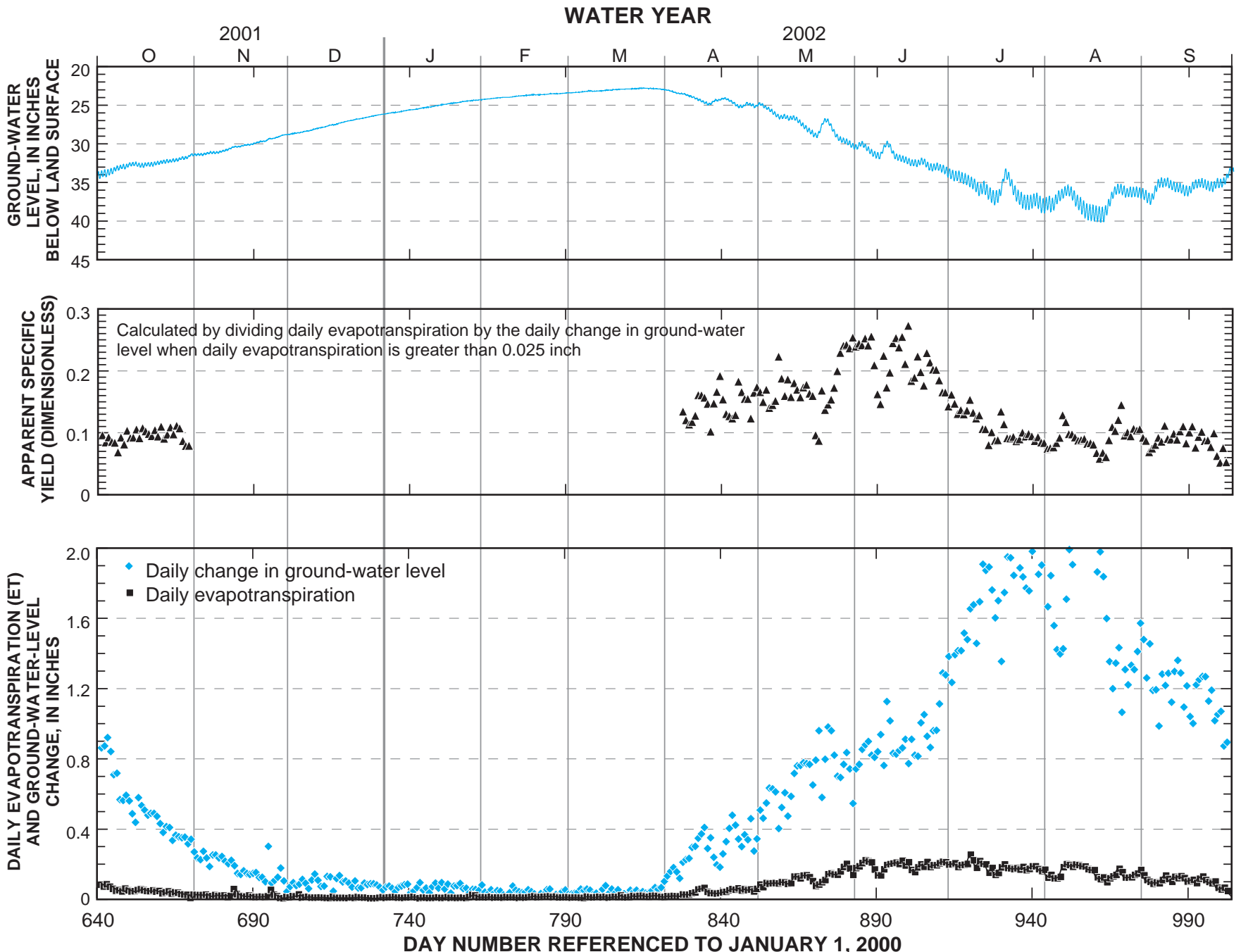

Figure 20. Ground-water level, daily evapotranspiration (ET), daily change in ground-water level, and apparent specific yield at the Grapevine Springs ET site, water year 2002. Apparent specific yield calculated as daily evapotranspiration divided by daily change in measured ground-water level.

The one exception is Miller (1977, p. 25 and 33), who provides an estimate of total discharge from the Grapevine Springs complex. He estimates annual discharge from the spring complex at more than 725 acre-ft and ET at 700 acre-ft. These estimates are based on selected springflow measurements and an estimated phreatophyte area of about 150 acres, of which 100 acres are densely vegetated. Based on Miller's numbers, the area-weighted annual ET rate of the Grapevine Springs vegetation would be $4.7 \mathrm{ft}$. A rate of this magnitude is not supported in the literature. The discharge estimate for Grapevine Springs presented in this report (405 acre-ft; table 14), assumes about 191 acres of phreatophyte vegetation and an area-weighted ground-water ET rate of about $2.1 \mathrm{ft} / \mathrm{yr}$ - a rate generally consistent with, although slightly lower than, literature-reported values for similar vegetation (DeMeo and others, 2003, p. 24; Reiner and others, 2002, table 5).
Acknowledging that a rate of $2.1 \mathrm{ft} / \mathrm{yr}$ may be too low for the high-density vegetation in the Grapevine Springs area (see "Limitations of Methodology" section), discharge was computed using an area-weighted ground-water ET rate of $2.8 \mathrm{ft} / \mathrm{yr}$ - the value given in Reiner and others (2002, table 5) for dense meadow vegetation in nearby Oasis Valley. Assuming that this higher ET rate better represents the highdensity vegetation at Grapevine Springs, the mean annual ground-water discharge computed using 191 acres (table 14) is 535 acre-ft. Allowing for some uncertainty in the ET rate, a range bracketing a reasonable estimate of the ground water discharged annually by the riparian vegetation at Grapevine Springs is from 400 to 550 acre- $\mathrm{ft}$. 
Table 14. Estimated mean annual ground-water discharge by evapotranspiration from major spring-discharge areas along the eastern margin of Death Valley.

[ET, evapotranspiration; MDV, moderate-density vegetation; HDV, high-density vegetation. Discharge area locations shown in figures 8 and 9. ET-unit descriptions listed in table 3. Annual ground-water ET calculated as product of the unit's acreage and ground-water ET rate. Mean annual ground-water discharge by ET calculated as the sum of annual ground-water ET volumes calculated for each ET unit]

\begin{tabular}{|c|c|c|c|c|c|}
\hline \multirow{2}{*}{$\begin{array}{l}\text { Spring- } \\
\text { discharge } \\
\text { area }\end{array}$} & \multicolumn{4}{|c|}{ ET unit } & \multirow{2}{*}{$\begin{array}{l}\text { Mean annual } \\
\text { ground-water } \\
\text { discharge by ET, } \\
\text { in acre-feet }\end{array}$} \\
\hline & Identifier & $\begin{array}{l}\text { Acreage, } \\
\text { in acres }\end{array}$ & $\begin{array}{l}\text { Ground-water } \\
\text { ET rate, in } \\
\text { feet per year }\end{array}$ & $\begin{array}{l}\text { Annual ground- } \\
\text { water ET, in } \\
\text { acre-feet }\end{array}$ & \\
\hline \multicolumn{6}{|c|}{ Grapevine Springs imagery } \\
\hline \multirow[t]{2}{*}{ Grapevine Springs } & MDV & 79.4 & 2.0 & 158.8 & \multirow{2}{*}{405} \\
\hline & HDV & 111.9 & 2.2 & 246.2 & \\
\hline \multirow[t]{2}{*}{ Surprise Springs } & MDV & 4.1 & 2.0 & 4.8 & \multirow{2}{*}{9} \\
\hline & HDV & 2.2 & 2.2 & 4.4 & \\
\hline \multirow[t]{2}{*}{ Staininger Spring } & MDV & 20.9 & 2.0 & 49.3 & \multirow{2}{*}{49} \\
\hline & HDV & 22.4 & 2.2 & 0 & \\
\hline \multicolumn{6}{|c|}{ Furnace Creek imagery } \\
\hline \multirow[t]{2}{*}{ Nevares Springs } & MDV & 13.6 & 2.0 & 27.2 & \multirow{2}{*}{61} \\
\hline & HDV & 15.4 & 2.2 & 33.9 & \\
\hline \multirow[t]{2}{*}{ Cow Creek-Salt Springs } & MDV & 5.0 & 2.0 & 10 & \multirow{2}{*}{21} \\
\hline & HDV & 5.1 & 2.2 & 11.2 & \\
\hline \multirow[t]{2}{*}{ Texas Spring } & MDV & 5.4 & 2.0 & 10.8 & \multirow{2}{*}{24} \\
\hline & HDV & 5.8 & 2.2 & 12.8 & \\
\hline \multirow[t]{2}{*}{ Travertine Springs } & MDV & 9.8 & 2.0 & 19.6 & \multirow{2}{*}{45} \\
\hline & HDV & 11.6 & 2.2 & 25.5 & \\
\hline
\end{tabular}

\section{Limitations of Methodology}

The overall accuracy of the estimates given for groundwater discharge by ET depends on the validity of the assumptions made in calculating volumetric discharge; and on any errors in the acreage, ET rate, and ground-water ET rate estimated for delineated ET units. Assumptions affecting the accuracy of discharge estimates are: (1) that the precipitation component of ET can be removed by subtracting measured precipitation at the site, (2) that no sources other than precipitation and ground water contribute water to ET, (3) that ground water is evaporated and transpired only from those areas delineated as part of an ET unit, (4) that the variation in ET within a discharge area can be adequately described using only two ET units, and (5) that ET rates assigned to each ET unit adequately represent the average for that unit. The estimate also depends on the validity of the assumption that all springflow and seepflow is evaporated or transpired internally. The potential error resulting from any of these assumptions is not expected to significantly alter the estimates presented in this report.

Errors associated with acreage estimates are largely dependent on the quality and resolution of the multispectral imagery and on the method used to delineate ET units. IKONOS imagery is appropriate for identifying most phreatophyte distributions within the spring-fed discharge areas of the study area. Although ET units were delineated for discharge areas in both the Grapevine Springs and Furnace Creek imagery, a rigorous field-based verification was done only for the Grapevine Springs discharge area. Verification of the ET units delineated in other discharge areas was done only by comparing remotely sensed delineations with high resolution color-infrared images and aerial photographs. It is expected that delineations of ET units in the Furnace Creek imagery could be improved with field-based refinement. Acreage estimates for ET units in discharge areas within the Grapevine Springs imagery are considered more accurate as a result of field verification.

Delineations based on multiple years of multi-spectral imagery would provide more confidence in estimates intended to represent the long-term average of vegetated acreage. ET-unit delineations and acreages were determined from imagery acquired on a single date (June 10, 2001, for the Furnace Creek area; and July 16, 2001, for the Grapevine Springs area). Late June (near the summer solstice) typically is considered the period of the year when the phreatophytic vegetation is of high vigor. Because of poor atmospheric conditions, good-quality imagery for the Grapevine Springs area could not be acquired earlier than mid-July 2001. 
However, higher-than-normal precipitation in the first one-half of 2001 maintained robust vegetation throughout July, making the Grapevine Springs imagery acceptable for mapping ET units by multi-spectral methods (fig. 16). Although these dates are assumed adequate for mapping average vegetation and soil conditions, some changes in vegetation do occur from one year to the next. Annual vegetation changes result from increases or decreases in precipitation, which affects local vegetation, soil-moisture conditions, and the depth to the water table-all of which affect ET rates. Potential errors in estimates of the annual ET rate are linked to limitations in the Bowen ratio solution and the assumption that the values estimated represent annual and spatial averages. Because mean annual ET was computed from measurements made during a relatively short period (about 2 years) and at a limited number of ET sites, the confidence in these estimates could be improved with additional temporal and spatial data. Limitations specific to the Bowen ratio solution are discussed in Laczniak and others (1999) and Ohmura (1982).

The slight southwest slope of the canopy surface may affect the accuracy of the annual ET rate estimated for highdensity vegetation at the Grapevine Springs ET site. Ideally, the fetch of the site should be flat when using the Bowen ratio to solve the energy budget. To evaluate the effect of a slightly sloping surface at the site, the net radiation measured over a 10-day, active period of ET was corrected for a 10-percent south-southwest slope using theoretical adjustments given in Frank and Lee (1966). This analysis indicated that the corrected daily net radiation was at most 10 percent greater than measured net radiation. Assuming the worst case- that the 10 percent increase in net radiation translates to 10 percent greater annual ET for high-density vegetation - the mean annual discharge for the Grapevines Springs discharge area would increase from 405 acre-ft (table 13) to 428 acre-ft. This higher volume is already within the estimated range of 400-550 acre-ft for annual ground-water discharge by riparian vegetation from the Grapevine Springs discharge area. A higher annual ET rate for the high-density ET also may be appropriate for other discharge areas in the study area. Although a higher annual ET rate would increase the volume estimated, the increase depends on the acreage estimated for high-density vegetation within a particular discharge area.

Estimates of mean annual ET for moderate- and highdensity vegetation are based on limited spatial data. Some spatial and temporal variability is expected in delineated ET units. Longer term data and additional ET-site installations would increase confidence in annual ET estimates presented in this report.

As stated previously in this report, estimates of groundwater discharge account only for ground water lost to the atmosphere by evapotranspiration, and are not inclusive of any springflow diverted, evaporated, or transpired outside the discharge area. Absent knowledge or estimates of other outflow, values given in this report should be considered minimum estimates of the volume of ground water discharged from these major spring complexes.

\section{Summary}

Ground water flowing from major springs and seeps along the eastern margin of Death Valley supplies most of the water consumed locally, and also sustains much of the unique habitat in Death Valley National Park. Together these spring complexes constitute the terminus of the DVRFS - one of the larger flow systems in the Southwestern United States. The Grapevine Springs complex is the least exploited for water supply and consequently contains the largest area of undisturbed riparian habitat in the park.

More accurate and reliable estimates of ground-water discharge are needed to document the water requirements of sensitive spring-fed habitats and to develop a better understanding of the long-term sustainability of the groundwater resource. The USGS, in cooperation with the National Park Service, began a 3-year study in 2000 to develop an estimate of mean annual ground-water discharge from the Grapevine Springs area and estimates of the amount of ground water transpired by the local riparian vegetation within each of the major spring discharge areas along the eastern margin of Death Valley. Results of the study are intended to establish a sound basis for estimating water rights, and also provide baseline information for determining and documenting any future changes in ground-water discharge in the park.

The assumption used to estimate local discharge from the spring-fed riparian areas along the eastern margin of Death Valley is that ET rates vary with the health, density, and type of the vegetation and wetness of the soil. These variations can be adequately characterized by a finite number of generalized spatial groupings (ET units) delineated using multi-spectral imagery. The approach first computes ET for each ET unit as the product of its acreage and a representative ET rate, and then calculates ET for a discharge area by summing ET computed for each of its component ET units.

High-resolution multi-spectral imagery was used to group riparian vegetation in each major spring discharge area into two unique ET units discriminated on the basis of vegetation density. This high-resolution imagery was acquired by the IKONOS satellite. This satellite is equipped with multispectral sensors that measure reflected solar radiation within four bands, each of which spans a discrete wavelength within the visible or near-infrared regions of the electromagnetic spectrum. The satellite also acquires a panchromatic band that spans a broader portion of the electromagnetic spectrum. The imagery resolution is 13.1 feet for multi-spectral bands and 3.28 feet for the panchromatic band.

Two areas, each encompassing about 39 square miles, were imaged within Death Valley. Imagery of the Furnace Creek area was acquired on June 10, 2001, and imagery of the Grapevine Springs area was acquired on July 16, 2001. Each image was orthorectified to improve its spatial accuracy and calibrated to reduce astronomic and atmospheric effects. The imagery was calibrated to field-acquired spectral data measured over a black tarp (dark reflector) and white tarp (bright reflector) on or near the day the imagery was acquired. 
Two different procedures were applied to delineate ET units using IKONOS imagery. Both procedures delineated the two ET units in each discharge area-one unit representing high-density and the other moderate-density vegetation. One procedure developed pixel groupings on the basis of differences in a vegetation index, while the other used a landcover classification. Because the primary focus of the study was Grapevine Springs, the criteria used to delineate ET units was developed in the Grapevine Springs area and applied to the other major spring discharge areas along the eastern margin of Death Valley.

ET units first were delineated on the basis of the modified soil-adjusted vegetation index (MSAVI). This index was selected because it best reduces soil influences. The MSAVI, as is typical of most vegetation indices, is calculated using the percent reflectance of the red (band 3) and near-infrared (band 4) wavelengths. ET-unit acreage in the Grapevine Springs area determined from MSAVI values totaled about 192 acres - of which 80 acres were moderate-density vegetation and 112 acres were high-density vegetation. ETunit acreage for all major discharge areas in the Grapevine Springs imagery (Grapevine Springs, Staininger Springs, and Surprise Springs) totaled 239 acres, and ET-unit acreage for all major spring discharge areas in the Furnace Creek imagery (Nevares Springs, Cow Creek-Salt Springs, Texas Spring, and Travertine Springs) totaled about 74 acres. Springflow diversions and turf watering have altered the distribution of the natural vegetation in discharge areas other than Grapevine Springs.

ET units also were delineated using a land-cover classification. The land-cover classification grouped pixels into two ET units on the basis of similarities between reflectance values in all four multi-spectral bands of the IKONOS imagery. Although the ET-unit acreages delineated within the Grapevine Springs imagery by land-cover classification were nearly equivalent to those delineated from MSAVI values, delineations in major discharge areas in the Furnace Creek imagery differed by as much as 50 percent. Based on comparisons of ET-unit delineations with aerial photographs and high-resolution infrared images, the distributions and acreages delineated from MSAVI values were considered more accurate.

A ground-water ET rate for high-density vegetation was estimated from micrometeorologic data collected at a site in the Grapevine Springs area. The site was in a dense vegetation cluster dominated by desert wild grape. ET at the site was computed using the Bowen ratio to solve the energy budget. Instrumentation included paired temperature and humidity probes, multiple soil heat-flux plates, multiple soil temperature and moisture probes, a net radiometer, and bulk rain gage. In addition, a pressure sensor was set in a nearby shallow well to acquire information on the daily and annual watertable fluctuation. Micrometeorologic data were collected at 20-minute intervals and water levels were collected at hourly intervals. Bulk precipitation was measured about monthly during each field visit. The site was selected specifically to allow year-round access and to meet the fetch criteria required by the Bowen ratio solution. Two surface-flow sites located along primary drainage channels were established in the vicinity of the ET site. Flow measurements were made during each site visit using a portable Parshall flume.

Data collection started in September 27, 2000, and ended in November 4, 2002. Precipitation data indicate that about 90 percent of the nearly 7.5 inches of measured rainfall fell during the first one-half of the 2-year study period. Trends in water-level, surface-water-discharge, temperature, and humidity data all show responses to the greater precipitation period. Water levels fluctuated about 1.2 feet annually over the 2-year collection period and were a few tenths of a foot higher in water year 2001 than in 2002. Surface-water discharge ranged from a high of about 25 gallons per minute in late winter to a low of less than 1 gallon per minute in late summer. The seasonal decrease in surface-water discharge was attributed to increasing evapotranspiration by the local riparian vegetation.

ET at the Grapevine Springs ET site generally begins increasing in late spring and peaks in the early through midsummer period (June and July). During this peak period, daily ET ranged from about 0.18 to $0.25 \mathrm{inch}$, and monthly ET ranged from about 5.7 to 6.2 inches. ET totaled about 2.7 feet in water year 2001 and about 2.3 feet in water year 2002. The difference in precipitation between the two water years is nearly equivalent to the difference in annual ET. Annual trends in daily ET show an inverse relation with water levels—as ET begins increasing in April, water levels begin declining, and as ET begins decreasing in September, water levels begin rising. The slightly greater ET and higher water levels in water year 2001 compared with water year 2002 are assumed to be a response to greater precipitation.

Daily water-level fluctuation varied from near zero in the mid-winter months to a maximum of about 2.3 inches in the mid- and late-summer months. During the active ET period (late spring through summer), the daily water-level change exceeded the daily ET. Similarities between ET and waterlevel trends indicate that ET is the primary process removing water from the water table.

The rate at which ground water is transpired at the Grapevine Springs ET site was calculated by subtracting measured precipitation from computed ET. The mean annual ground-water ET rate was calculated by averaging values computed for three different 365-day periods within the 2year period of record. The ground-water component of ET 
at the Grapevine Springs ET site ranged from 2.1 to 2.3 feet, with the mean annual ground-water ET from high-density vegetation being 2.2 feet. A value of 2.0 feet was used to represent the mean annual discharge of ground water by moderate-density vegetation.

The mean annual discharge of ground water by ET for discharge areas in the Grapevine Springs imagery ranged from 9 to 405 acre-feet, and in the Furnace Creek imagery ranged from 21 to 61 acre-feet. The highest estimate, 405 acre-feet, is from the Grapevine Springs discharge area, and the lowest estimate, 9 acre-feet, is from the Surprise Springs discharge area.

The estimate of ground-water discharge by ET given for the Grapevine Springs discharge area also represents the amount of ground water discharged annually from the area's local springs and seeps and the ground-water requirement of the area's natural riparian vegetation. Estimates of the total volume of ground water discharged from other major spring discharge areas were not attempted primarily because of uncertainties associated with ongoing diversions. Acknowledging some uncertainty in the estimate of the ET rate, a range bracketing a reasonable estimate for groundwater discharge by riparian vegetation at Grapevine Springs is 400-550 acre-feet.

The overall accuracy of the estimates given for groundwater discharge by ET depends on the validity of the assumptions made to calculate volumetric discharge and errors in acreages, ET rates, and ground-water ET rates estimated for delineated ET units. Assumptions that affect the overall accuracy of discharge estimates are: (1) the precipitation component of ET can be removed by subtracting measured precipitation at the site, (2) no sources other than precipitation and ground water contribute to ET, (3) ground water is evaporated and transpired only from those areas delineated as part of an ET unit, (4) the variation in evapotranspiration within a discharge area can be described using only two ET units, and (5) ET rates assigned to each ET unit adequately represent the average values for the area. The estimate of ground-water discharge depends on the validity of the assumption that all springflow and seepflow is evaporated internally or transpired. The potential error resulting from these assumptions is not expected to greatly alter any of the estimates given in this report.

Estimates of ground-water discharge given in this report account only for ground water locally lost to the atmosphere by evapotranspiration and are not inclusive of any springflow diverted, evaporated, or transpired outside the discharge area. Absent knowledge of estimates of other outflow, values given in this report should be considered minimum estimates of the volume of ground water discharged at major spring complexes along the eastern margin of Death Valley.

\section{Acknowledgments}

The authors express their appreciation to National Park Service (NPS) for allowing access to the study site, and to the many NPS staff who provided assistance on various tasks - usually on very short notice. The authors thank David I. Stannard of the U.S. Geological Survey for graciously providing technical guidance when requested. The authors also thank William D. Nichols (recently deceased) of the U.S. Geological Survey who tirelessly mentored project personnel on the application of evapotranspiration theory and instrumentation in the desert environments of Nevada and California. Lastly, the authors thank the Timbisha Shoshone Tribe for endorsing and supporting this effort and for allowing entry onto sacred lands.

\section{References Cited}

American Society of Photogrammetry, 1983, Manual of remote sensing: Falls Church, Va., The Sheridan Press, $2440 \mathrm{p}$.

Anderson, J.S., Hardy, E.E., Roach, J.T., and Witmer, R.E., 1976, A land use and land cover classification system for use with remote sensor data: U.S. Geological Survey Professional Paper 964, 28 p.

Berger, D.L., Johnson, M.J., Tumbusch, M.L., and Mackay, Jeffrey, 2001, Estimates of evapotranspiration from the Ruby Lake National Wildlife Refuge Area, Ruby Valley, northeastern Nevada, May 1999-October 2000: U.S. Geological Survey Water-Resources Investigations Report 01-4234, $38 \mathrm{p}$.

Bowen, I.S., 1926, The ratio of heat losses by conduction and by evaporation from any water surface: Physics Review, v. 27 , p. $779-787$.

D’Agnese, F.A., Faunt, C.C., Turner, A.K., and Hill, M.C., 1997, Hydrogeologic evaluation and numerical simulation of the Death Valley Regional Ground-Water Flow System, Nevada and California: U.S. Geological Survey WaterResources Investigations Report 96-4300, 124 p.

Daly, C., Nielson, R.P., and Phillips, D.L., 1994, A statisticaltopographic model for mapping climatological precipitation over mountainous terrain: Journal of Applied Meteorology, v. 33, p. 140-158.

DeMeo, G.A., Laczniak, R.J., Boyd, R.A., Smith, J.L., and Nylund, W.E., 2003, Estimated ground-water discharge by evapotranspiration from Death Valley, California, 1997-2001: U.S. Geological Survey Water-Resources Investigations Report 03-4254, 27 p. 
Frank, E.C., and Lee, R., 1966, Potential solar beam irradiation on slopes: tables for $30^{\circ}$ to $50^{\circ}$ Latitude: U.S. Forest Service Research Paper RM-18, 116 p.

Goetz, A.F.H., Rock, B.N., and Rowen, L.C., 1983, Remote sensing for exploration-An overview: Economic Geology, v. 78 , no. 4 , p. $573-590$.

Harrill, J.R., Gates, J.S., and Thomas, J.M., 1988, Major ground-water flow systems in the Great Basin region of Nevada, Utah, and adjacent states: U.S. Geological Survey Hydrologic Investigations Atlas HA-694-C, scale 1:1,000,000, 2 sheets.

Hunt, C.B., Robinson, T.W., Bowles, W.A., and Washburn, A.L., 1966, Hydrologic basin, Death Valley, California: U.S. Geological Survey Professional Paper 494-B, 138 p.

Laczniak, R.J., DeMeo, G.A., Reiner, S.R., Smith, J.L., and Nylund, W.E., 1999, Estimates of ground-water discharge as determined from measurements of evapotranspiration, Ash Meadows area, Nye County, Nevada: U.S. Geological Survey Water-Resources Investigations Report 99-4079, $70 \mathrm{p}$.

Laczniak, R.J., Smith, J. LaRue, Elliott, P.E., DeMeo, G.A., Chatigny, M.A., and Roemer, G.J., 2001, Ground-water discharge determined from estimates of evapotranspiration, Death Valley Regional Flow System, Nevada and California: U.S. Geological Survey Water-Resources Investigations Report 01-4195, $51 \mathrm{p}$.

Malmberg, G.T., 1967, Hydrology of the valley-fill and carbonate-rock reservoirs, Pahrump Valley, NevadaCalifornia: U.S. Geological Survey Water-Supply Paper $1832,47 \mathrm{p}$.

Malmberg, G.T., and Eakin, T.E., 1962, Ground-water appraisal of Sarcobatus Flat and Oasis Valley, Nye and Esmeralda Counties, Nevada: Nevada Department of Conservation and Natural Resources, Ground-Water Resources - Reconnaissance Series Report 10, 39 p.

Miller G.A., 1977, Appraisal of the water resources of Death Valley, California and Nevada: U.S. Geological Survey Open-File Report 77-728, 67 p.
Nichols, W.D., 2000, Regional ground-water evapotranspiration and ground-water budgets, Great Basin, Nevada: U.S. Geological Survey Professional Paper 1628, $82 \mathrm{p}$.

Ohmura, Atsumu, 1982, Objective criteria for rejecting data for Bowen ratio flux calculations: Journal of Applied Meteorology, p. 595-598.

Pistrang, M.A., and Kunkel, Fred, 1964, A brief geologic and hydrologic reconnaissance of the Furnace Creek Wash Area, Death Valley National Monument, California: U.S. Geological Survey Water-Supply Paper 1779-Y, 35 p.

Qi, J., Chehbouni, A., Huerte, A.R., Kerr, Y.H., and Sorooshian, S., 1994, A modified soil adjusted vegetation index: Remote Sensing Environment, v. 48, p. 119-126.

Reiner, S.R., Laczniak, R.J., DeMeo, G.A., Smith, J.L., Elliott, P.E., Nylund, W.E., and Fridrich, C.J., 2002, Ground-water discharge determined from measurements of evapotranspiration, other available hydrologic components, and shallow water-level changes, Oasis Valley, Nye County, Nevada: U.S. Geological Survey Water-Resources Investigations Report 01-4239, 65 p.

Stewart, J.H., 1980, Geology of Nevada: Nevada Bureau of Mines and Geology Special Publication 4, 136 p.

Tou, J.T., and Gonzalez, R.C., 1974. Pattern recognition principles: Reading, Massachusetts, Addison-Wesley Publishing Co., $320 \mathrm{p}$.

Walker, G.E., and Eakin, T.E., 1963, Geology and ground water of Amargosa Desert, Nevada-California: Nevada Department of Conservation and Natural Resources, Ground Water Resources-Reconnaissance Report 14, 45 p.

Winograd, I.J., and Thordarson, William, 1975, Hydrogeologic and hydrochemical framework, south-central Great Basin, Nevada-California, with special reference to the Nevada Test Site: U.S. Geological Survey Professional Paper 712-C, $126 \mathrm{p}$. 
For more information concerning the research in this report, contact Director, Nevada Water Science Center

U.S. Geological Survey

2730 N. Deer Run Road

Carson City, Nevada 89701

http://nevada.usgs.gov/ 


\section{एँ}

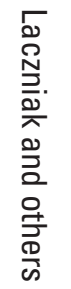

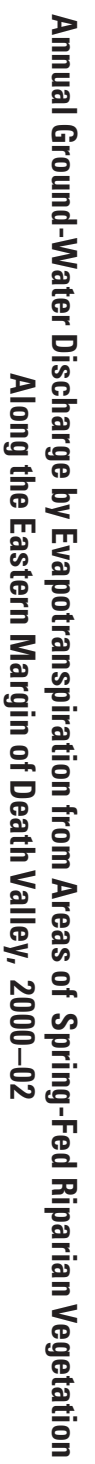

